\title{
19. MAGNETOSTRATIGRAPHY OF SITES 699 AND 700, EAST GEORGIA BASIN ${ }^{1}$
}

\author{
E. A. Hailwood ${ }^{2}$ and B. M. Clement ${ }^{3}$
}

\begin{abstract}
ODP Sites 699 and 700 were drilled within the East Georgia Basin primarily to explore the paleoceanographic and sedimentary history of this region during the early stages of separation of South America from Africa and Antarctica. Determination of the timing of the various events represented in the sedimentary record of these sites requires the establishment of a high-resolution stratigraphic framework. This was achieved through combined magnetostratigraphic/biostratigraphic studies of the sediments recovered from Holes 699A and 700B. The magnetostratigraphic data are presented in this paper. They are based on a combination of shipboard whole-core paleomagnetic determinations made at $10-\mathrm{cm}$ intervals on all archive core halves and involving AF demagnetization in fields of 5 and/or $9 \mathrm{mT}$ together with shipboard and post-cruise incremental AF demagnetization analyses of some 450 discrete samples.

A generally continuous magnetostratigraphic record has been obtained for the Pliocene-Pleistocene and Oligocene sequences recovered from Hole 699A. A record of the Brunhes, Matuyama, and late Gauss Chrons has been identified in the Pleistocene to late Pliocene age sediments cored in the upper $30-\mathrm{m}$ section of this hole. However, interpretation of the magnetostratigraphic record observed for the Pliocene sediments in the interval from 30 to 70 mbsf is complicated by the possible presence of hiatuses.

A well-defined sequence of normal and reverse polarity magnetozones was identified for the Oligocene sequence of Hole 699A in the interval from 85 to 219 mbsf. Although there are few biostratigraphic datums for this interval, the observed polarity sequence shows a good correlation with geomagnetic polarity Chrons C6CR to C11R.

As a result of poor core recovery, the magnetostratigraphic sequence for the early Oligocene to early Eocene age sediments from 243 to $468 \mathrm{mbsf}$ in Hole $699 \mathrm{~A}$ is discontinuous. However, available biostratigraphic datums allow the identification of Chrons C13N and C13R in the depth interval from 270 to 306 mbsf and the Chron sequence C20R to $\mathrm{C} 22 \mathrm{R}$ in the interval from 397 to $465 \mathrm{mbsf}$.

The sedimentary sequence recovered from Hole 700B extends from the middle Eocene through to the Coniacian or Turonian stages. The magnetostratigraphic record for the Eocene part of this sequence is fragmentary, but chronal assignments can be made for certain isolated parts of the section. In contrast, a well-defined succession of magnetozones established for the Paleocene to Late Cretaceous age part of the section correlates well with the polarity time scale between Chrons C26R and C34N. Biostratigraphic (nannofossil) data indicate that a hiatus may be present at the Cretaceous/Tertiary boundary. However, the magnetostratigraphic data indicate the probable presence of a reverse polarity magnetozone at this level, which can be correlated with the reverse interval (Chron C29R) known to span the Cretaceous/Tertiary boundary. The record of the preceding Chron C30N is anomalously short at this site. These data indicate that sedimentation may have been continuous across the Cretaceous/Tertiary boundary and that the hiatus is located instead within late Maestrichtian age Chron C30N.
\end{abstract}

\section{INTRODUCTION}

During Leg 114 of the Ocean Drilling Program (ODP) a series of sites was drilled in a transect across the southern South Atlantic at a latitude of $\sim 50^{\circ} \mathrm{S}$ in order to explore the oceanographic history of this region throughout the late Mesozoic and Cenozoic. A particular aim of this drilling was to investigate the development of the important deep-water connections between the Antarctic and South Atlantic oceans, which had profound influences on Cenozoic world ocean circulation and paleoclimates. The location of the Leg 114 drill sites is shown on a generalized cross section of the southern South Atlantic in Figure 1.

Paleogeographic reconstructions of the southern South Atlantic region, based mainly on seafloor-spreading magnetic anomaly data, indicate that the major "gateway" for deep-

${ }^{1}$ Ciesielski, P. F., Kristoffersen, Y., et al., 1991. Proc. ODP, Sci. Results, 114: College Station, TX (Ocean Drilling Program).

2 Department of Oceanography, University of Southampton, $\mathrm{SO} 95 \mathrm{NH}$, U.K.

${ }^{3}$ Ocean Drilling Program, Texas A\&M University, 1000 Discovery Drive, College Station, TX 77845-9547 (Present address: Department of Geology, Florida International University, College of Arts and Sciences, University Park, Miami, FL 33199). water circulation between the Antarctic and South Atlantic began to develop in the late Paleocene as a result of rifting of the Islas Orcadas Rise away from the Meteor Rise (LaBrecque and Hayes, 1979). The history of opening of this gateway was explored through drilling at ODP Sites 701 through 704 (Fig. 1), and results of which are described elsewhere in this volume. Prior to the opening of the Islas Orcadas Rise-Meteor Rise gateway, an earlier, more limited connection between the Antarctic and developing South Atlantic Ocean basins may have existed across the East Georgia Basin, a topographic low situated between the Islas Orcadas Rise and the Northeast Georgia Rise (Fig. 1). ODP Sites 699 and 700 were drilled within this basin in order to explore its sedimentary history and paleoceanography. Specific objectives of the drilling included documenting the development of the southern highlatitude biosiliceous province of the Antarctic Circumpolar Current and the influence of the opening of the Drake Passage and other Neogene tectonic events on the sedimentary history of the region. These objectives required establishing a highresolution stratigraphy that would provide the necessary time framework for the sedimentary succession cored at Sites 699 and 700 . Standard calcareous microfossil biostratigraphic zonations have been developed primarily for low-latitude species, and their applicability to the relatively high latitudes of these sites is uncertain and largely untested. There is a need to 


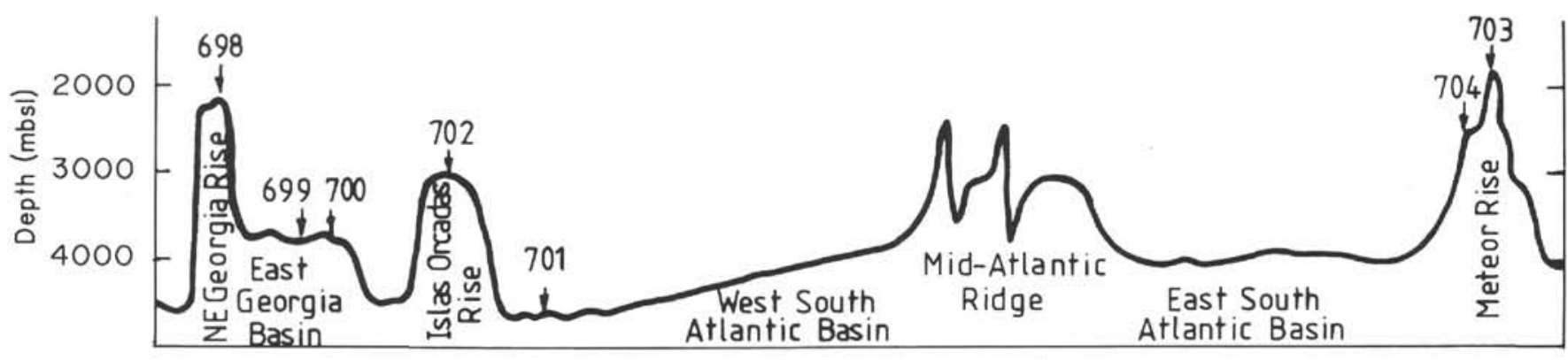

$1000 \mathrm{Km}$

Figure 1. Schematic bathymetric profile across the southern South Atlantic showing the location of the Leg 114 drill sites and the principal bathymetric features referred to in this paper.

refine these zonations and to develop new zonations for high-latitude species, particularly for siliceous organisms. Consequently, an important component of the stratigraphic work on the sediments cored on Leg 114 was the development of a magnetostratigraphy to permit a correlation of the highlatitude biostratigraphic zones identified in these sediments to a geomagnetic polarity time scale (GPTS) and thence to standard low-latitude biostratigraphic zonations.

This paper describes the paleomagnetic analyses carried out on these sediments and presents the resulting magnetostratigraphy. Biostratigraphic datums identified in the sediments, which were previously calibrated against the GPTS, were used to correlate the observed sequence of magnetozones to the GPTS.

\section{PALEOMAGNETIC MEASUREMENTS}

The three different systems used for making paleomagnetic determinations from the sediments recovered at ODP Sites 699 and 700 are the shipboard whole-core cryogenic (WCC) magnetometer, the shipboard discrete sample spinner (DSS) magnetometer, and the discrete sample cryogenic (DSC) magnetometer system in the Southampton University paleomagnetic laboratory.

The shipboard WCC system (manufactured by 2-G Enterprises) is designed for paleomagnetic measurement of complete $1.5-\mathrm{m}$ sections of core or longitudinally split core halves. Normally measurements are made on the archive core half and are taken at $5-$ or $10-\mathrm{cm}$ intervals along the entire length of the section. The system uses a three-axis sensor, which allows simultaneous measurement of three orthogonal components of magnetization of the core, and thus determination of the vector resultant, at each measurement point. A threeaxis alternating field (AF) demagnetizer is mounted in-line with the magnetometer to permit progressive demagnetization of the core half in applied fields of intensity up to $9 \mathrm{mT}$. This allows removal of low-stability components of magnetization acquired in the present geomagnetic field at the drill site or during handling and storage of the core aboard ship. Despite unusually rough seas and excessive ship motion throughout Leg 114, the shipboard WCC system remained remarkably stable and provided reliable paleomagnetic determinations for even the most weakly magnetized sediments recovered.

The shipboard DSS system consists of a Molspin spinner magnetometer and a Schonstedt single-axis AF demagnetizer. It is designed to provide paleomagnetic determinations from standard ODP discrete paleomagnetic samples contained in 6-mL rectangular plastic boxes. In the present study the DSS system was used to assess the reliability of the WCC system. Several specimens from each major lithostratigraphic unit at the two sites were subjected to detailed shipboard incremental
AF demagnetization, in applied fields up to $50 \mathrm{mT}$ using this system, in order to confirm the effectiveness of the half-core AF demagnetization in removing low-stability magnetic overprints.

The Southampton University DSC magnetometer system consists of a dual-axis cryogenic magnetometer, manufactured by Cryogenic Consultant Ltd., with a built-in AF demagnetizer. The sample remains within the magnetically shielded magnetometer system throughout the entire demagnetization sequence and is moved between the "measure" and "demagnetize" positions by an automated sample-handler system. A total of 453 discrete samples from the two sites was processed on this system, with each sample incrementally demagnetized in applied fields of $2.5,5,7.5$, and $10 \mathrm{mT}$. A representative subset of specimens was further demagnetized at $5-\mathrm{mT}$ intervals up to a maximum field of $35 \mathrm{mT}$.

\section{SEDIMENTS}

One hole (Hole 699A) was drilled at Site 699 using the advanced hydraulic piston corer (APC) to a depth of $205.1 \mathrm{~m}$ below seafloor (mbsf), and then with the extended core barrel (XCB) corer to a total depth of $518.1 \mathrm{mbsf}$. The recovered sequence consists of Neogene siliceous oozes (Unit I) and nannofossil diatom oozes (Unit II) overlying a thin Oligocene gravel bed (Unit III) at 235 mbsf. Beneath this, Eocene/ Oligocene siliceous nannofossil oozes (Unit IV) overlie Eocene nannofossil chalks (Unit V) and late Paleocene age zeolite-bearing claystone (Unit VI) to a total depth of 489 mbsf. Rough seas encountered during drilling at this site resulted in greater core disturbance than normally observed in APC cores, and the sea state as well as the occurrence of gravel beds in the sequence hampered recovery. Core recovery averaged more than $80 \%$ in the APC cores, but only $61 \%$ in the XCB cores.

Site 700 is located some $21 \mathrm{~km}$ east of Site 699 . Two holes were drilled at this site. Hole $700 \mathrm{~A}$ penetrated only to a depth of 9.6 mbsf whereas Hole $700 \mathrm{~B}$ penetrated to $489 \mathrm{mbsf}$. Paleomagnetic analyses were focused on the latter hole. The sedimentary succession cored at Site 700 consists of a thin unit of diatom ooze (Unit I) overlying a thick sequence of chalks and limestones. These show progressive lithification with depth from ooze (Unit II, 26-45 mbsf), through friable chalk (Unit III, 45-228 mbsf), to indurated chalk (Unit IV, 228-319 mbsf) and limestone (Unit V, 319-489 mbsf).

A major objective of drilling at this site was to investigate the nature of the basement and the overlying Cretaceous sediments, which had not been reached at Site 699 because of the loss of the drill bit. The necessary use of rotary drilling at Site 700 in attempting to achieve this objective resulted in a higher degree of drilling disturbance in the upper part of the 
cored section than would have been expected had the APC or XCB system been used. The most common form of drilling disturbance in these cores was "biscuiting" (breaking of the core into small disk-shaped pieces, commonly only a few centimeters in length). Downhole contamination from particles of strongly magnetic glacial erratics and seafloor ferromanganese concretions was also a problem that particularly interfered with the acquisition of reliable whole-core paleomagnetic data for the upper part of the hole. For these reasons the paleomagnetic record for the upper $270 \mathrm{~m}$ in Hole $700 \mathrm{~B}$ is based exclusively on measurements of discrete samples. However, good whole-core data were obtained beneath this level.

\section{MAGNETIC INTENSITY}

Determinations of directions of remanent magnetization made on the archive core halves, using the WCC magnetometer, agree closely (typically to within a few degrees) with determinations made with the discrete sample systems. However, determinations of magnetic intensity on the WCC magnetometer generally show poor correspondence with those made on the other two systems. This is due, at least in part, to the fact that no allowance is made in the WCC system for variations in the effective volume of the split core section along its length, which result from incomplete filling of the core liner or variations in the core diameter and thickness of the split section. In general, the discrete sample intensity data are more reliable, and the values reported in this paper are those obtained with the DSC instrument.

The variation of natural remanent magnetization (NRM) intensity with depth in the two holes is shown in Figures 2 and 3 , together with the principal lithostratigraphic unit boundaries. In Hole 699A the different lithostratigraphic units generally have distinct magnetic intensities (Fig. 2). Thus, the

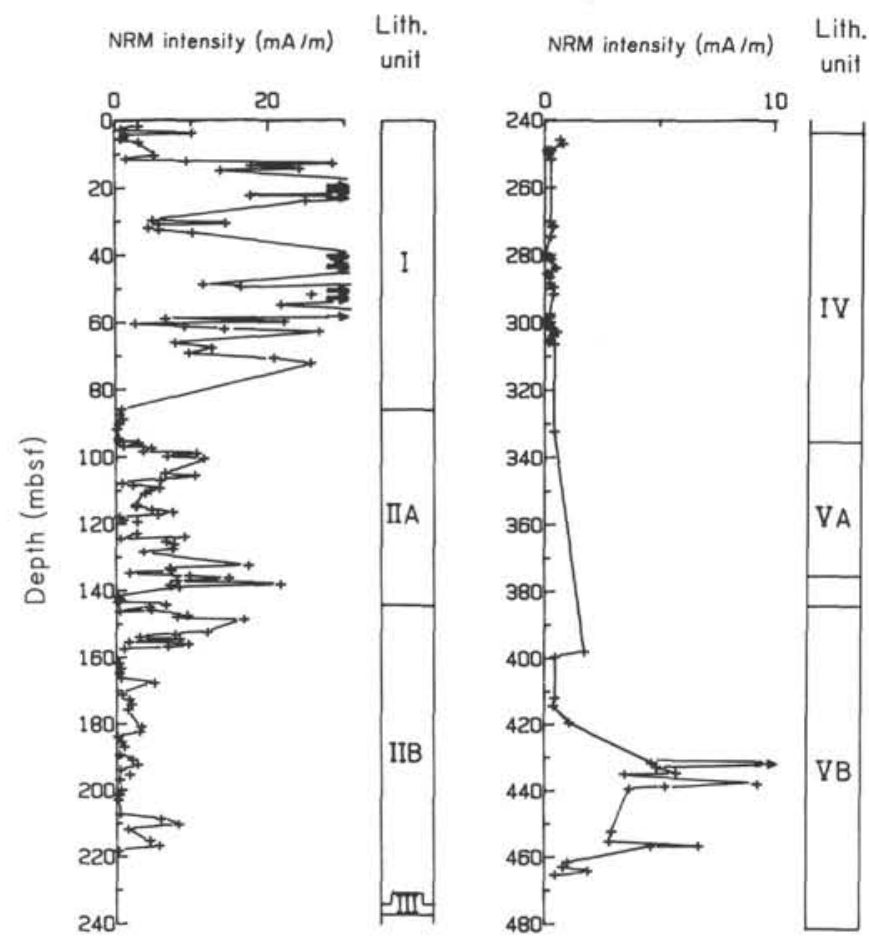

Figure 2. Variation of NRM intensity with depth in Hole 699A, determined from discrete sample measurements. Principal lithostratigraphic unit boundaries are shown. Note that the intensity scale changes at $240 \mathrm{mbsf}$.
Neogene siliceous oozes of Unit I have significantly higher magnetic intensities than the diatom oozes of Unit II. The Eocene/Oligocene siliceous nannofossil oozes of Unit IV have notably low intensities, whereas the values for the underlying Eocene nannofossil chalk of Unit V are comparable to those for Unit II. In Hole 700B the differences in the intensity values for the different lithostratigraphic units are less distinct (Fig. 3 ). Zones of high magnetic intensity occur near the top and in the lower part of the nannofossil chalk sequence of Unit III, as well as in the micritic and clay-bearing limestones in the lower part of Unit V. However, the indurated nannofossil chalks of Unit IV are characterized by relatively weak magnetic intensities.

Isothermal remanent magnetization (IRM) analyses were made on representative specimens from each of the lithostratigraphic units and subunits in Holes 699A and 700B in order to obtain information on the types of magnetic minerals present (Figs. 4 and 5). Specimens from the high magnetic intensity units (Figs. 4A-4C and 4F for Hole 699A and Figs. 5A, 5B, 5E, and 5F for Hole 700B) invariably show a rapid increase in IRM intensity with applied field, and magnetic saturation is usually reached in applied fields of $0.3 \mathrm{~T}$ or less. This behavior indicates that the dominant magnetic mineral in the high magnetic intensity specimens is magnetite. In contrast, the specimens from the low magnetic intensity units (Figs. 4D and 4E for Hole 699A and Figs. $5 \mathrm{C}$ and $5 \mathrm{D}$ for Holes $700 \mathrm{~B}$ ) show a more gradual growth of IRM, with saturation commonly not completely reached in the maximum applied field used $(0.9 \mathrm{~T})$. This indicates that although magnetite grains probably are present in these specimens, the coercivity spectrum of these grains is broader than in the low magnetic intensity units and some other high-coercivity mineral (possibly hematite) is also present.

It is concluded that the principal factor controlling the observed fluctuations in magnetic intensity in these sediments

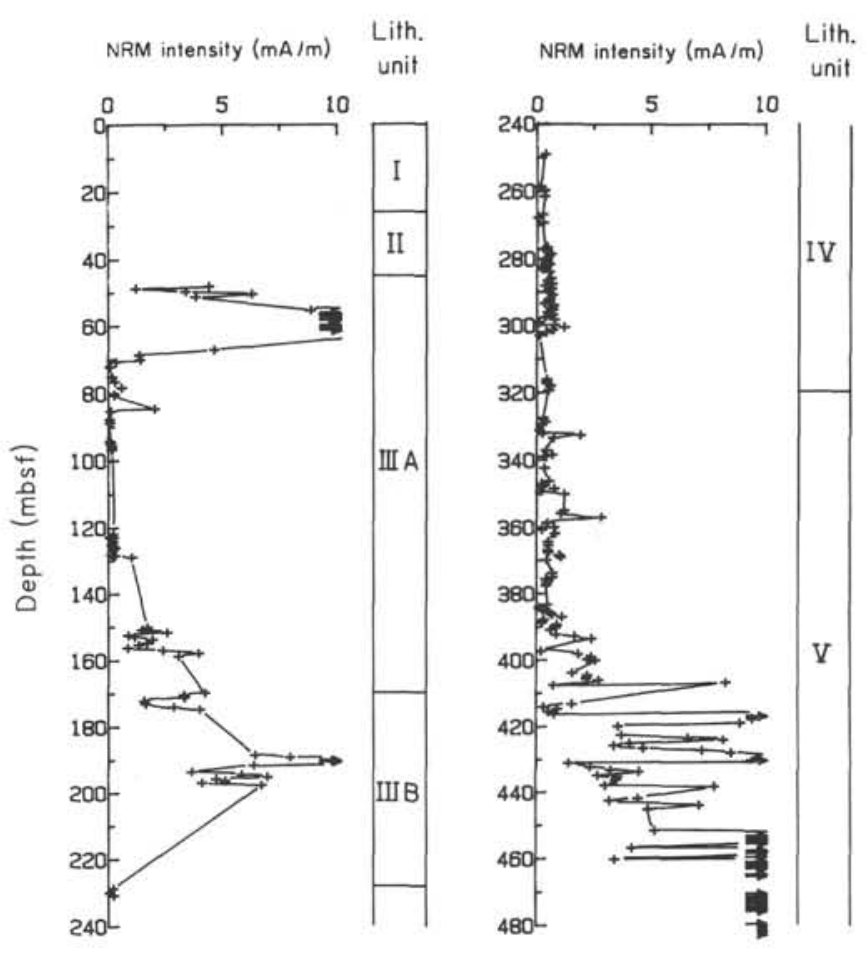

Figure 3. Variation of NRM intensity with depth in Hole 700B, determined from discrete sample measurements. Principal lithostratigraphic unit boundaries are shown. 


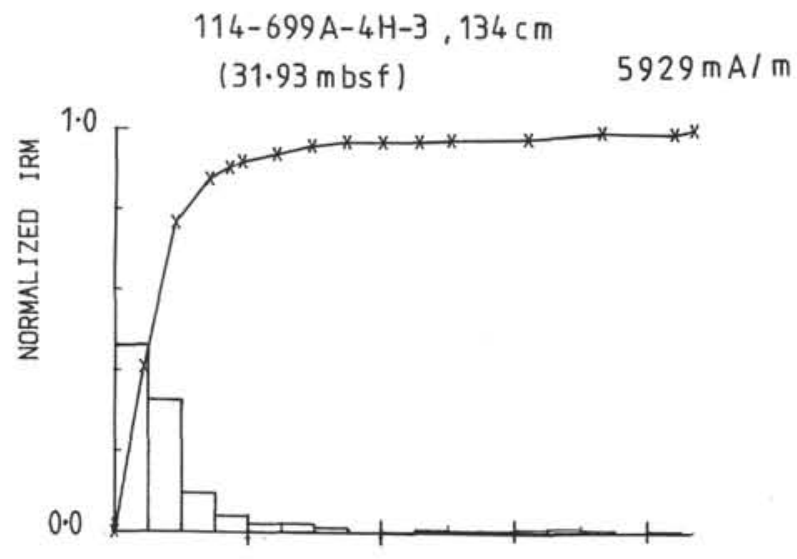

A
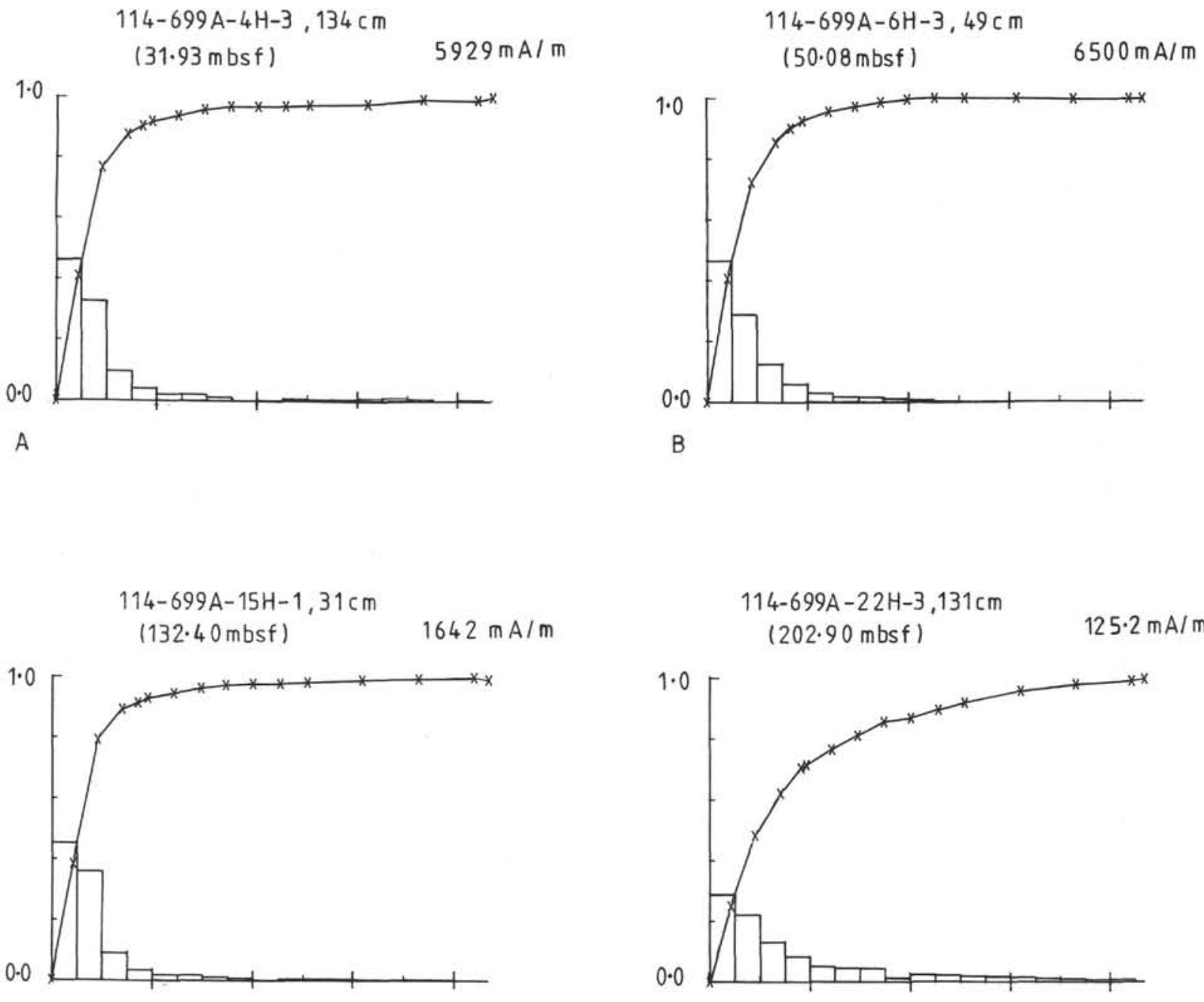

114-699A $-22 \mathrm{H}-3,131 \mathrm{~cm}$

(202.90 mbsf)

$125 \cdot 2 \mathrm{~mA} / \mathrm{m}$

C

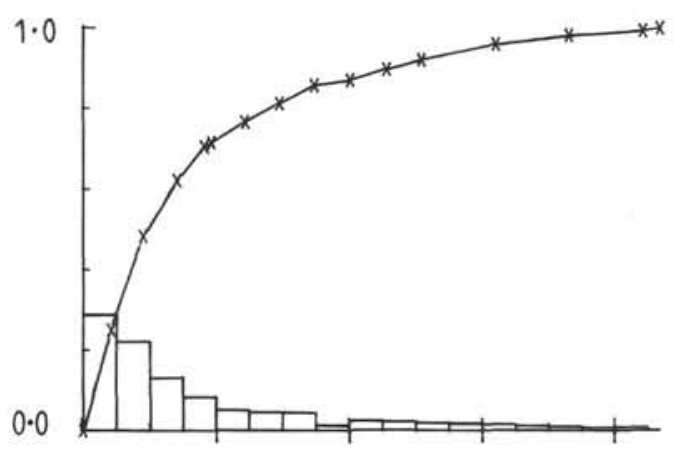

D

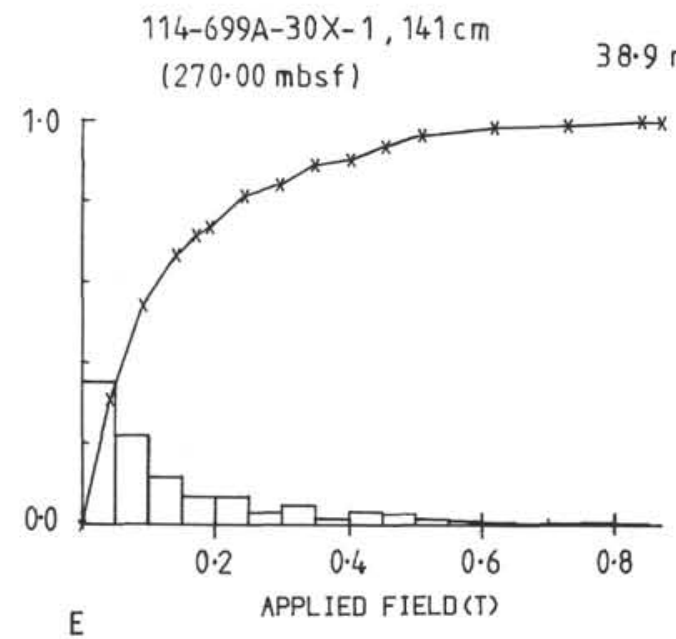

$38.9 \mathrm{~mA} / \mathrm{m}$

$114-699 A-47 X-2,123 \mathrm{~cm}$

$(432 \cdot 82 \mathrm{mbsf})$

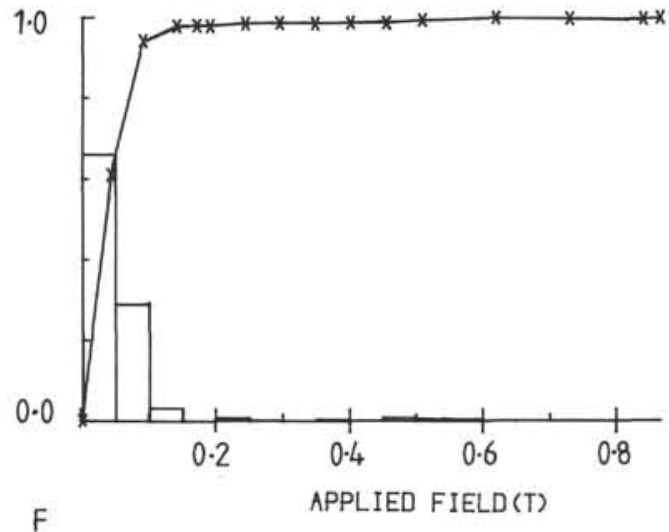

Figure 4. IRM-acquisition curves for representative specimens from Hole 699A show the variation of IRM intensity (normalized by the labeled maximum value) vs. the applied direct magnetic field. The associated histograms show the IRM acquired for each successive field increment. A-C. High magnetic intensity specimens from lithostratigraphic Unit I and Subunit IIA. D and E. Low magnetic intensity specimens from Subunit IIB and Unit IV. F. High magnetic intensity specimens from Subunit VB. Note the correlation between curve shape and magnetic intensity. 


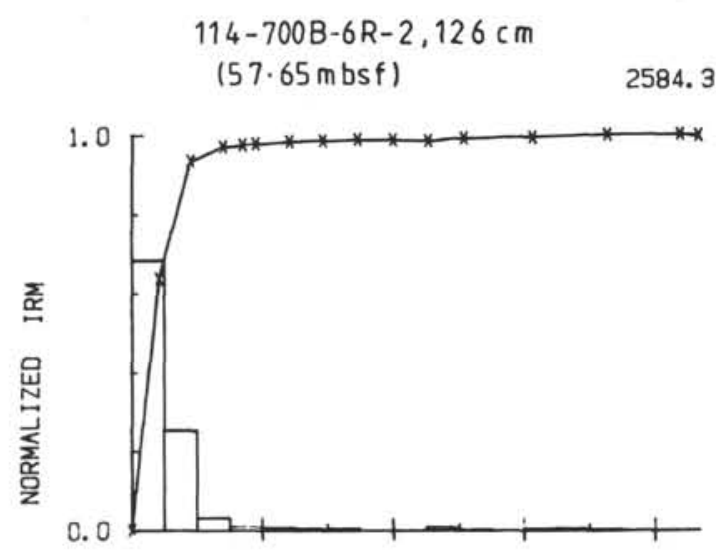

A

$114-700 \mathrm{~B}-30 \mathrm{R}-3,104 \mathrm{~cm}$

(280.00mbsf)

$91.5 \mathrm{~mA} / \mathrm{m}$

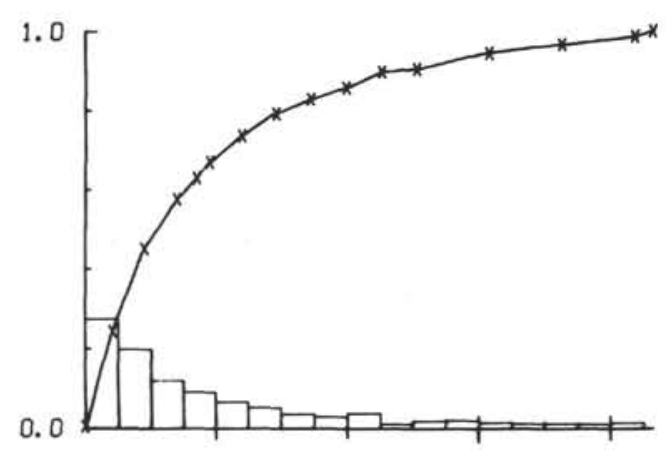

C

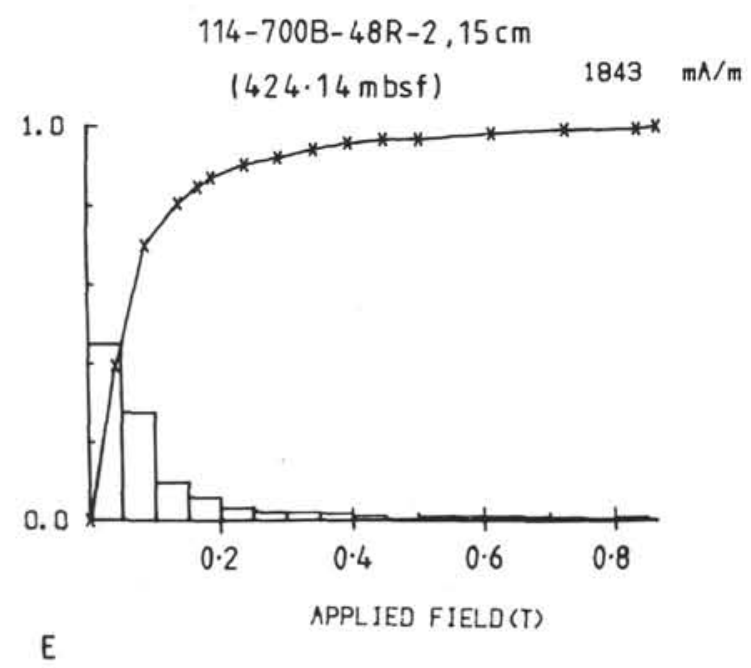

$114-700 B-20 \mathrm{R}-2,96 \mathrm{~cm}$

$(190.35$ mbsf)

$3466.4 \mathrm{~mA} / \mathrm{m}$

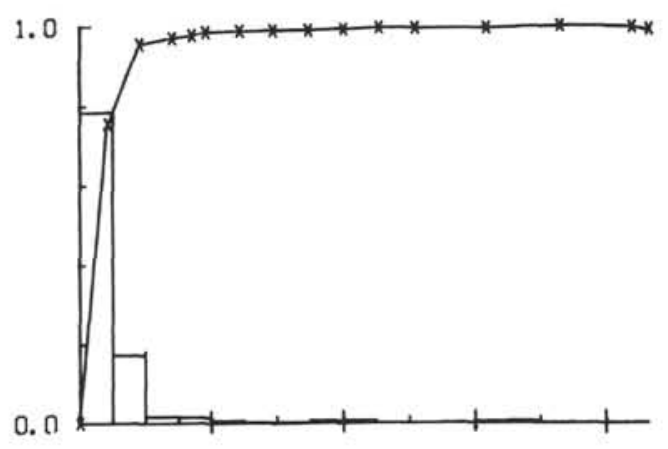

B
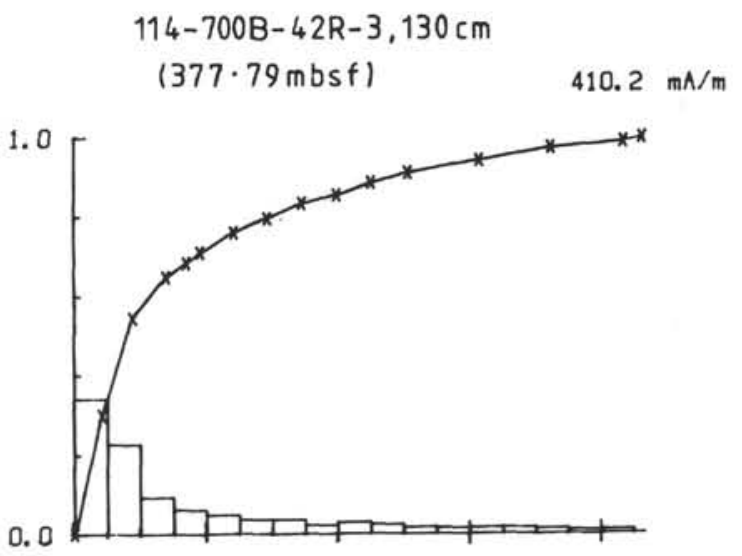

D

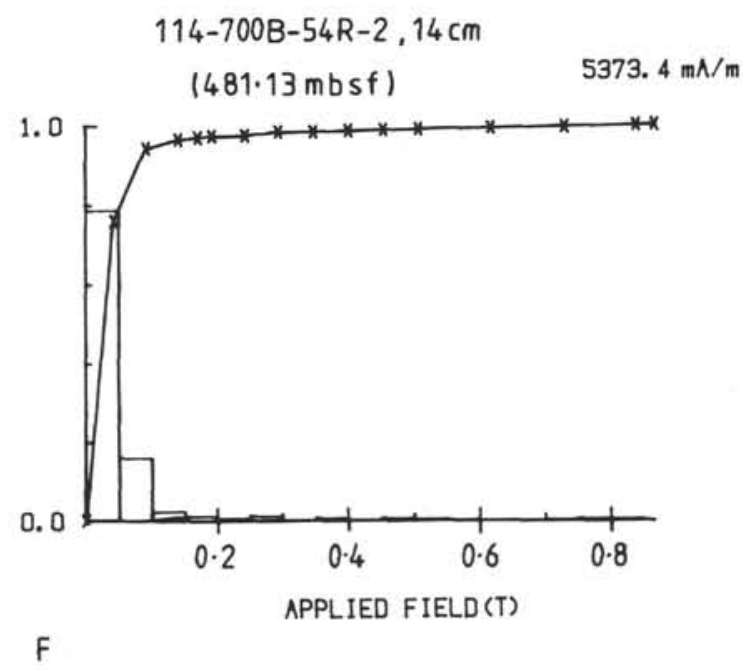

Figure 5. IRM-acquisition curves for representative specimens from Hole 700B. Symbols and conventions as in Figure 4. A and B. High magnetic intensity specimens from lithostratigraphic Unit III. C and D. Low magnetic intensity specimens from Units IV and V (upper). E and F. High magnetic intensity specimens from Unit V (lower). 
is variation in the composition of the magnetic minerals present. Such variations may reflect changes in sediment source area, changes in the relative abundance of terrigenous and biogenic magnetite, or possibly the influence of diagenetic processes.

\section{MAGNETIC STABILITY}

\section{Hole 699A}

A small subgroup of specimens from Hole 699A was subjected to incremental AF demagnetization in applied fields up to 40 or $50 \mathrm{mT}$, using the shipboard discrete sample system. The typical response of samples from the nannofossil diatom oozes of Unit II to this demagnetization treatment is shown in Figures $6 \mathrm{~A}$ and $6 \mathrm{~B}$. In some cases small directional changes, usually $<10^{\circ}$, occur in applied fields up to $5 \mathrm{mT}$, after which no further directional changes are observed as the magnetic intensity is progressively reduced to values of about $20 \%$ to $30 \%$ of the NRM. This indicates that the sediments carry a weak low-stability component of magnetization, which is preferentially destroyed during low-field AF demagnetization to isolate the higher stability characteristic component of magnetization.

The rest of the discrete samples were subjected to incremental AF demagnetization in applied fields up to $10 \mathrm{mT}$ using the Southampton DSC system. The response to this treatment (Figs. 6C and 6D) is essentially similar to that observed in the shipboard discrete sample demagnetization experiments. Prior to this treatment the samples were kept in refrigerated storage. Demagnetization at up to $10 \mathrm{mT}$ was completed within about 12 months of the end of the cruise. Some six months later several of the samples, which had been stored at room temperature in the laboratory since treatment at $10 \mathrm{mT}$ and had partially dried out, were subjected to further AF demagnetization in applied fields up to $35 \mathrm{mT}$. The direction of the stable characteristic magnetization of these samples was found to have changed by some $10^{\circ}$, usually toward a shallower inclination (Figs. $6 \mathrm{E}$ and $6 \mathrm{~F}$ ). It is concluded that the
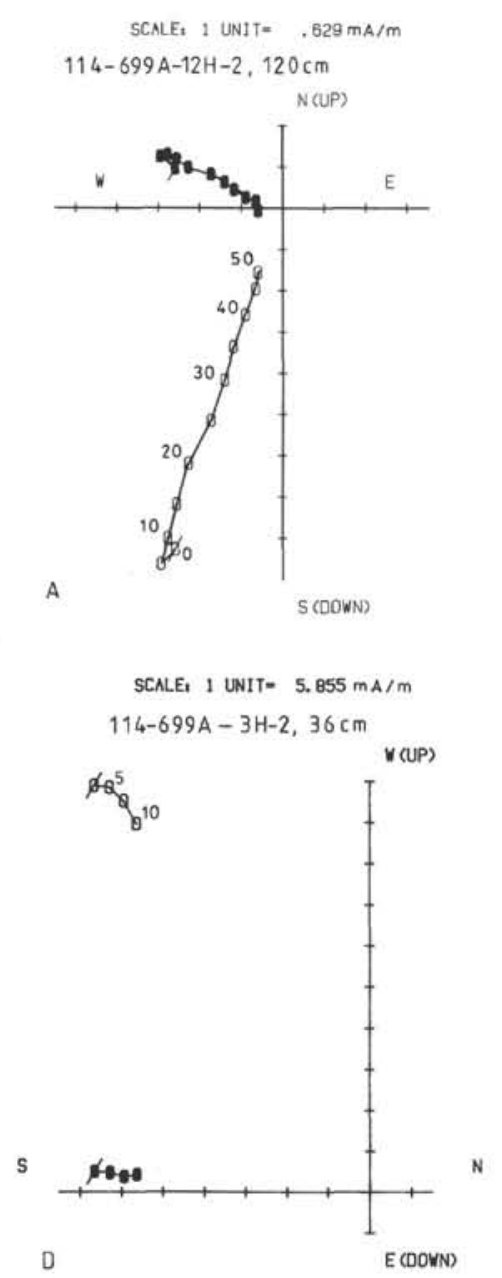
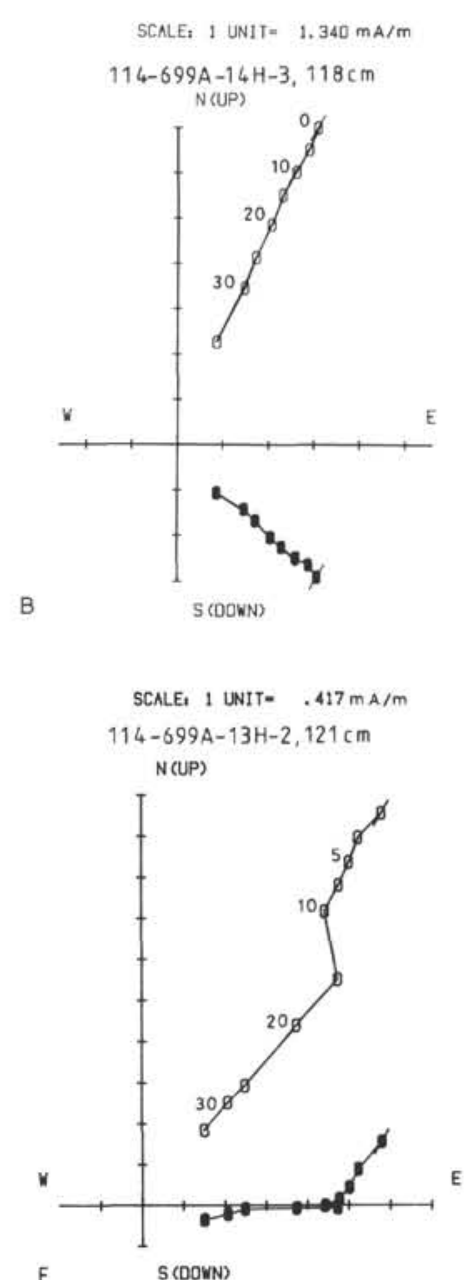
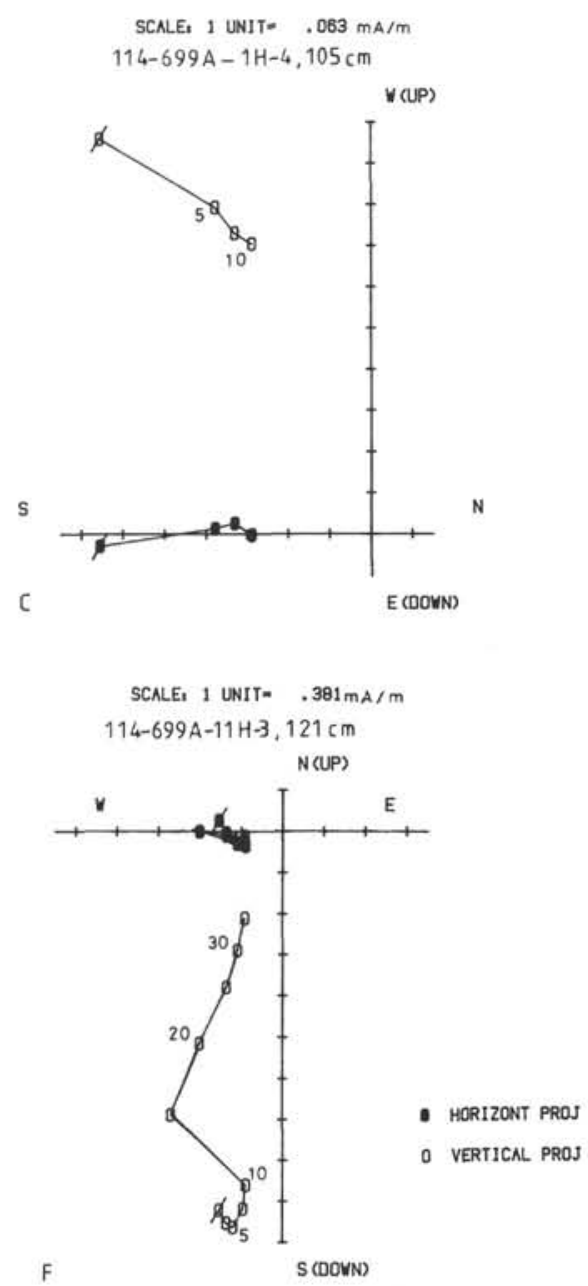

Figure 6. Response to AF demagnetization of typical samples from Quaternary to late Eocene age lithostratigraphic Units I through IV in Hole 699A. The paleomagnetic vectors are plotted on vector end-point diagrams (Zijderveld, 1967) that represent a pair of orthogonal planes (one horizontal and one vertical, with a common E-W or N-S axis). When only a single characteristic component of magnetism remains in the sample the points on these plots lie on a pair of straight lines directed toward the origin. Note that the azimuthal orientation of these cores is uncertain, so that $\mathrm{N}, \mathrm{S}, \mathrm{E}$, and $\mathrm{W}$ refer to an arbitrary azimuthal direction, $F$, which is perpendicular to the split surface of the core section. $\mathbf{A}$ and $\mathbf{B}$. Demagnetization behavior of nannofossil diatom oozes of Unit II obtained with the shipboard demagnetizer. C and D. Low-field demagnetization behavior of diatom oozes of Unit I obtained with the Southampton DSC demagnetizer. E and F. Changes in direction of characteristic magnetization after initial AF demagnetization at $2.5-\mathrm{mT}$ steps up to $10 \mathrm{mT}$, followed by laboratory storage for one year and partial drying out, and then further demagnetization at $5-\mathrm{mT}$ steps up to $35 \mathrm{mT}$. 
remanent magnetism of these sediments underwent modification during storage and drying. The linear segments of the vector plots defined by the last two steps of the initial demagnetization $(7.5$ and $10 \mathrm{mT})$ as well as those defined by the later demagnetization to $35 \mathrm{mT}$ are directed toward the origin of the vector plots. However, the pairs of linear segments for the two sets of treatment are quite distinct from each other.

This indicates that the storage and drying out resulted in a modification of the original remanent magnetization, rather than simply the superimposition of a later component on the unmodified original component. Thus, it is not possible to retrieve the original component by AF demagnetization. This behavior can be explained by a physical realignment of the magnetic mineral grains during drying, probably related to differential shrinkage of the sample along different axes, rather than the acquisition of a stable chemical remanent magnetization through alteration of the magnetic mineral grains or the acquisition of a viscous remanent magnetization in the laboratory geomagnetic field.

In view of this behavior further demagnetization of the other samples (all of which had partially dried out) was considered unprofitable and the direction of the stable component of magnetization in each discrete sample was determined from linear regression of the AF demagnetization vector plots for the initial AF treatment up to $10 \mathrm{mT}$.

All discrete samples from Quaternary to late Eocene age lithostratigraphic Units I through IV in Hole 699A showed small (generally $<10^{\circ}$ ) changes in direction of magnetization during incremental AF demagnetization, and in no case was a reverse polarity characteristic magnetization masked by a lower stability normal polarity overprint. However, this was not the case for the early to middle Eocene age nannofossil chalks of lithostratigraphic Unit V. Fourteen discrete samples from Unit V were subjected to incremental AF demagnetization in peak fields up to $30 \mathrm{mT}$. All reverse polarity samples analyzed carried a relatively strong normal polarity overprint, which was removed by demagnetization at $10 \mathrm{mT}$ (Fig. 7). Normal polarity samples showed no such directional change, but a rapid decrease of intensity occurred during the first few demagnetization steps (Fig. 8A). Clearly, these early to middle Eocene age sediments contain a higher proportion of low-coercivity magnetic grains than the younger sediments, allowing them to acquire a relatively strong magnetic overprint in the recent geomagnetic field at the sampling sites.

\section{Hole 700B}

Fifty discrete samples from Hole $700 \mathrm{~B}$ were subjected to AF demagnetization at 5 and/or $10 \mathrm{mT}$ using the shipboard DSS system. Six of these samples were then further demagnetized with this system at 5 - or $10-\mathrm{mT}$ increments up to a maximum field in the range 30 to $50 \mathrm{mT}$. A typical example of the response of the samples to this treatment is shown in Figure 8B. In all cases a weak low-coercivity component of remanence is removed by treatment in the range 5 to $10 \mathrm{mT}$, thus isolating a more stable component.

The remaining 251 samples from Hole $700 \mathrm{~B}$ were demagnetized using the Southampton DSC system, at 2.5-mT increments up to $10 \mathrm{mT}$. The results for typical samples carrying a normal polarity characteristic magnetization are illustrated in Figure $8 \mathrm{C}$ and for typical reverse polarity samples in Figure $8 \mathrm{D}$. In the vast majority of cases only small directional changes occur during the first two demagnetization steps, usually accompanied by a reduction in intensity of less than $10 \%$. Sample $114-700 \mathrm{~B}-6 \mathrm{R}-4,126 \mathrm{~cm}$, is one of the few samples showing a larger reduction in intensity. In all cases the results indicate the removal of a weak low-coercivity component in applied fields of $\sim 5 \mathrm{mT}$, with simple univectorial behavior thereafter.

\section{WHOLE-CORE DATA AND MAGNETIC POLARITIES}

Because of the relatively high magnetic latitude of Sites 699 and 700 , the geomagnetic field is steep $\left(\sim 70^{\circ}\right)$. Consequently, the inclination of the remanent magnetization in these sediments generally is better defined than the declination. Furthermore, azimuthal orientation of the cores is only possible using the APC system, in which cores are taken without rotation of the drill pipe. Even in these cores, technical problems with the orientation camera on Leg 114 led to uncertainties in the reliability of the azimuthal orientation data. Finally, there is evidence from APC cores taken at Site 704 (Hailwood and Clement, this volume) that the declination of remanent magnetism can be affected by the subsampling process. For these reasons the magnetic declination data were not used in the present study and magnetic polarities were deduced from the magnetic inclination data alone. Because the sites are situated at a high latitude in the Southern Hemisphere, normal polarities are indicated by negative inclination values and reverse polarities by positive inclination values.

The WCC system was used to measure the NRM of all archive core-half sections from these two sites. Sections from both sites were then routinely demagnetized at $5 \mathrm{mT}$, using the in-line AF demagnetizer, and the remanent magnetism remeasured. Where the magnetic polarity was not clearly established by this treatment the sections were further demagnetized at $9 \mathrm{mT}$ and remeasured.

The WCC inclination determinations made in this way are plotted in Figure 9 for Hole 699A and Figure 10 for Hole 700B along with the discrete sample (DSC) inclination values. The magnetic polarity shown in the figures is inferred from the combined data set. The depths of the principal polarity transitions in the two holes are listed in Tables 1 and 2.

\section{Short-Period Magnetic "Events"}

Within intervals of dominantly normal or reverse polarity, fluctuations in magnetic inclination values are common. Where these involve a change in sign of the inclination a decision must be made as to whether they represent true intervals of opposite polarity, shorter period magnetic excursions (i.e., "aborted reversals"), or simply large-amplitude features of the geomagnetic secular variation. The usual criterion for identifying a "true" geomagnetic reversal is that the field can be shown to have stabilized in the opposite polarity state, even for a short interval of time. However, the resolution of the sedimentary paleomagnetic record depends upon such factors as sedimentation rate, the influence of bioturbative mixing processes, and other postdepositional remanent magnetization processes. Consequently, rigid application of this criterion was not possible. Furthermore, the identification of true short-period geomagnetic reversals strictly requires both magnetic inclination and magnetic declination data.

In the present study the general rule used for identifying short polarity intervals and incorporating them into the polarity logs in Figures 9 and 10 is that they should be defined by more than one adjacent or closely associated inclination determination (either whole core or discrete sample) in excess of $40^{\circ}$. Where they are defined by a single (reliable) inclination value above this limit or more than one inclination value below the limit and extending over $>0.5 \mathrm{~m}$ of section, they may be included in the polarity log, but are marked with a query. No attempt has been made to distinguish between "true" polarity inversions and magnetic excursions. 

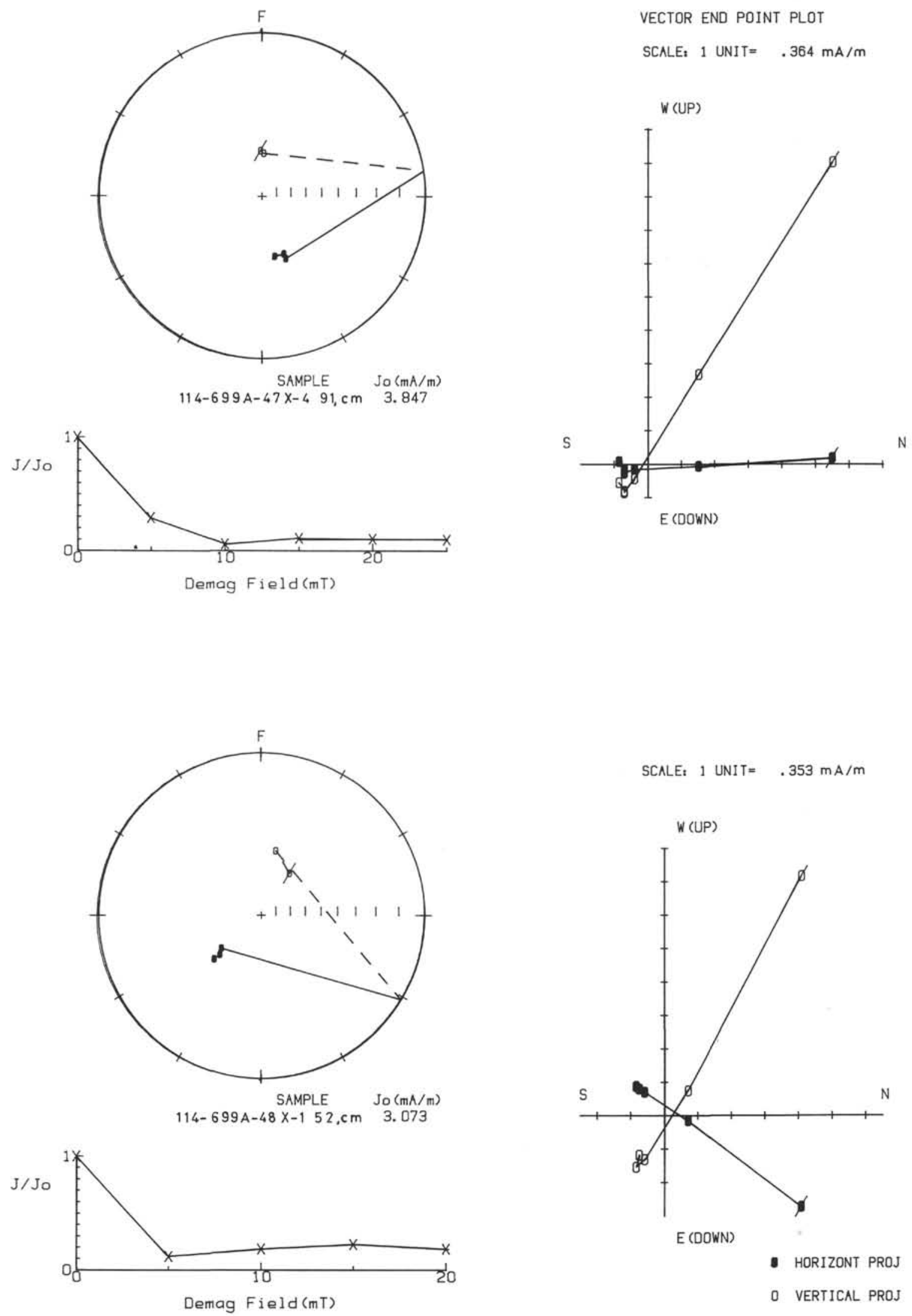

- VERTICAL PROJ

Figure 7. Response to AF demagnetization of samples of middle Eocene nannofossil chalks from lithostratigraphic Unit V of Hole 699A. These samples carry a reverse polarity characteristic magnetization. The direction of remanent magnetism after each demagnetization step is plotted on a stereographic projection (solid symbols, positive inclination; open symbols, negative inclination). Corresponding changes are shown for the magnetic intensity, $J$, normalized against the NRM value, Jo. The paleomagnetic vectors are plotted also on vector end-point diagrams (for explanation, see Fig. 6). 
$114-699 A-49 X-3,11 \mathrm{~cm}$

SCALE: 1 UNIT $=.343 \mathrm{~mA} / \mathrm{m}$

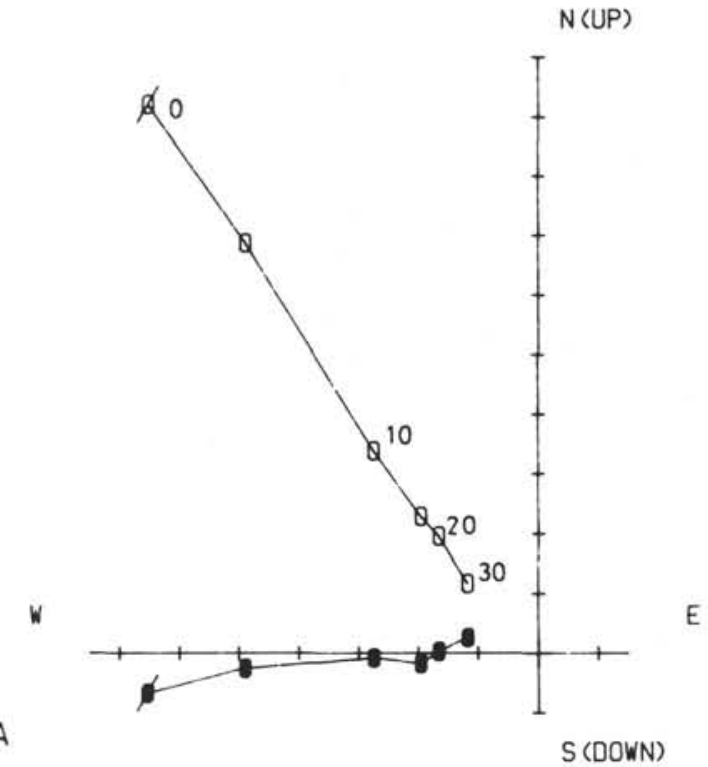

A

$114-700 \mathrm{~B}-6 \mathrm{R}-4,126 \mathrm{~cm}$

SCALE, 1 UNIT= .994 $\mathrm{mA} / \mathrm{m}$

W(UP)

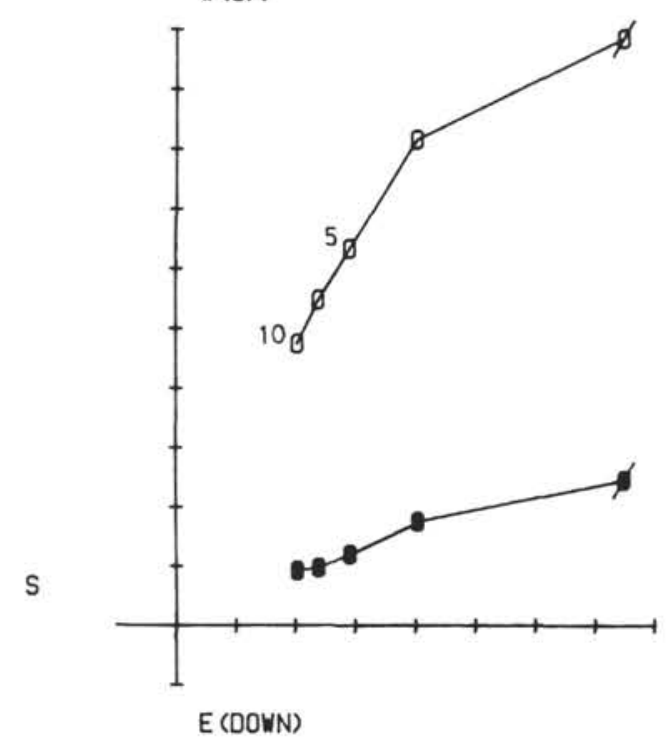

C
$114-700 \mathrm{~B}-51 \mathrm{X}-4,125 \mathrm{~cm}$

SCALE: I UNIT $=1.010 \mathrm{~mA} / \mathrm{m}$

S

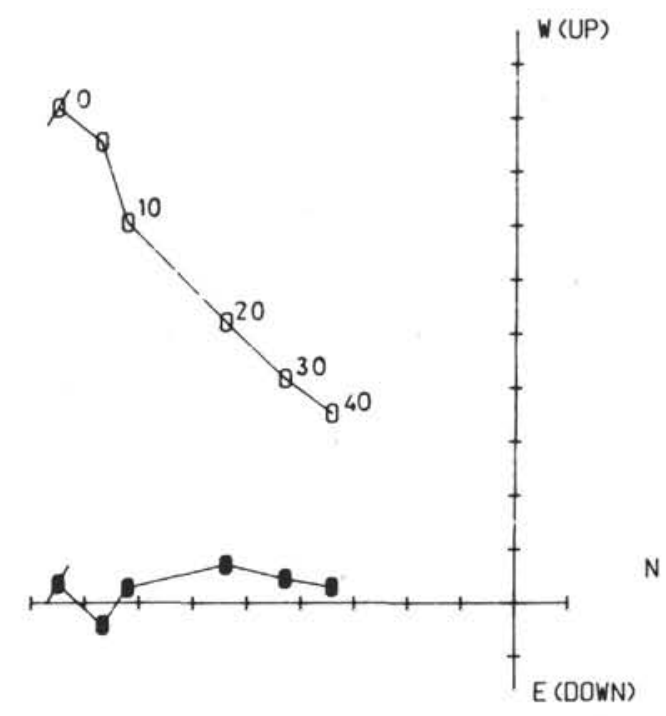

B

SCALE, 1 UNIT $=.300 \mathrm{~mA} / \mathrm{m}$

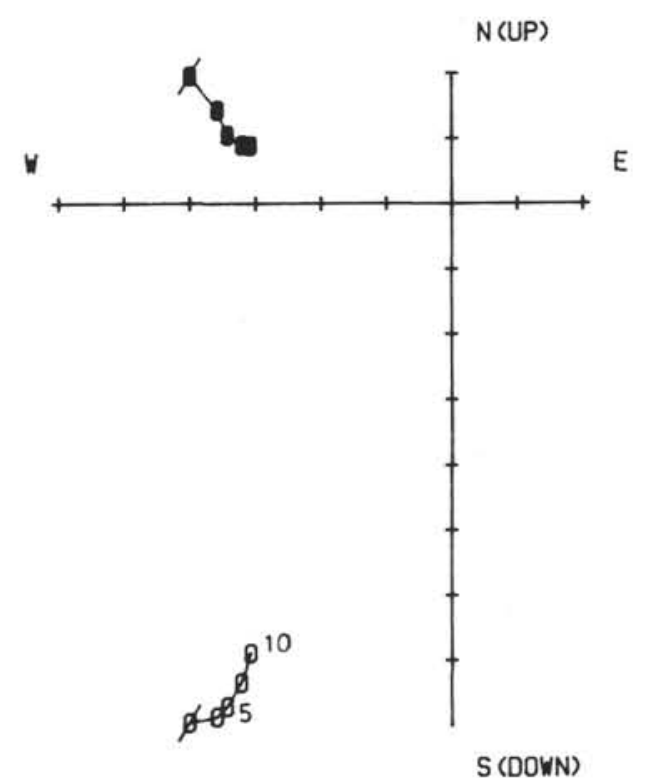

D

- HORIZONT PROJ

o VERTICAL PROJ

Figure 8. Response to low-field AF demagnetization. Symbols and conventions as in Figure 6. A. Middle Eocene nannofossil chalk with normal magnetic polarity from Hole 699A. B and C. Normal polarity samples from Hole 700B. D. Reverse polarity sample from Hole $700 \mathrm{~B}$. 
Inclination (degreos)

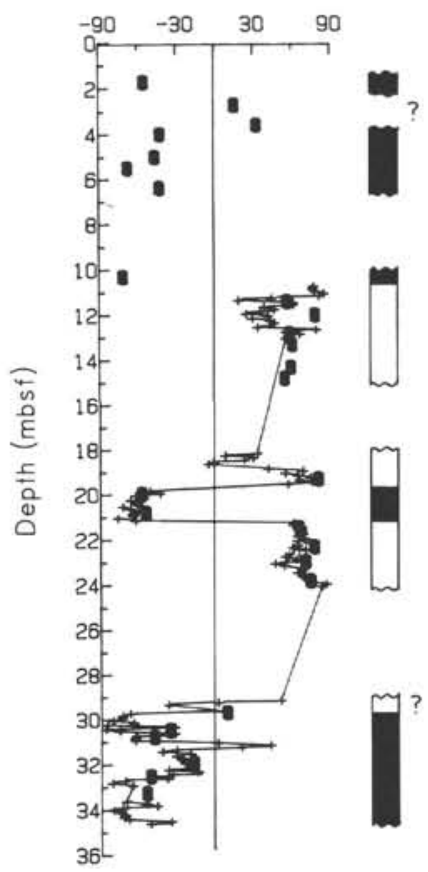

Inclination (dogroes)

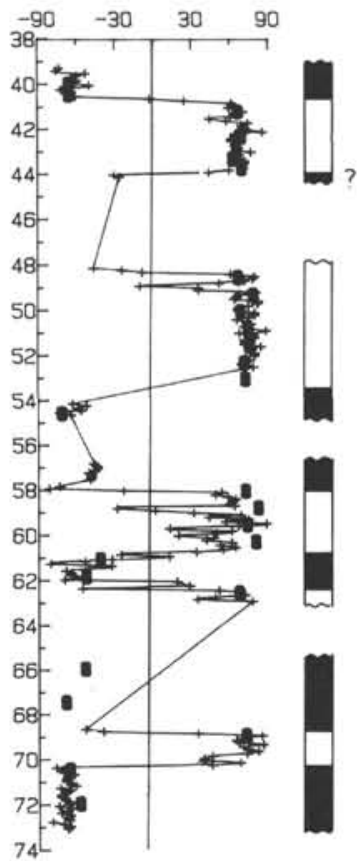

Figure 9. Variation of inclination of remanent magnetization and inferred magnetic polarity with depth in Hole 699A. Crosses indicate inclination determinations made on the shipboard whole-core magnetometer system, after AF demagnetization at either 5 or $9 \mathrm{mT}$. Solid symbols represent directions determined from incremental AF demagnetization measurements made on the Southampton cryogenic magnetometer system. In the polarity column black indicates normal polarity and white reverse polarity. As a result of core disturbance, no data are available for the intervals 74-90, 214.6-268.6, and 306.6392.1 mbsf. See text for discussion of the criteria used to define the polarity $\log$ from the observed inclination data.

\section{Hole 699A}

Good-quality WCC data were obtained for the depth range from 10 to 203 mbsf. However, because of excessive drilling disturbance and/or poor recovery, most of the sections below this depth were unsuitable for WCC measurements, and polarity determinations are based on DSC data alone. In general there is excellent correspondence between the magnetic polarity determinations based on the WCC measurements and those based on the DSC measurements (Fig. 9). Although the inclination values for the two data sets are similar over many depth intervals (e.g., 40 to $52 \mathrm{mbsf}$ ), the WCC inclination values are usually somewhat shallower than the DSC inclination values. This is more common for reverse polarity (positive inclination) intervals (e.g., 94-120 and 132137 mbsf) than for normal polarity (negative inclination) intervals (e.g., 144-149 mbsf).

This observation may be explained by the presence of a small normal polarity magnetic overprint that was not completely removed in the WCC analyses (thereby deflecting the resultant vector of reverse polarity samples toward the horizontal). The majority of the WCC data plotted in Figure 9 was obtained after AF demagnetization at $5 \mathrm{mT}$ whereas the DSC data were derived from demagnetization analyses in the range of 5 to $10 \mathrm{mT}$. Thus the DSC analyses may have been more effective in removing any normal polarity overprint present. However, the difference in treatment levels is quite small. An
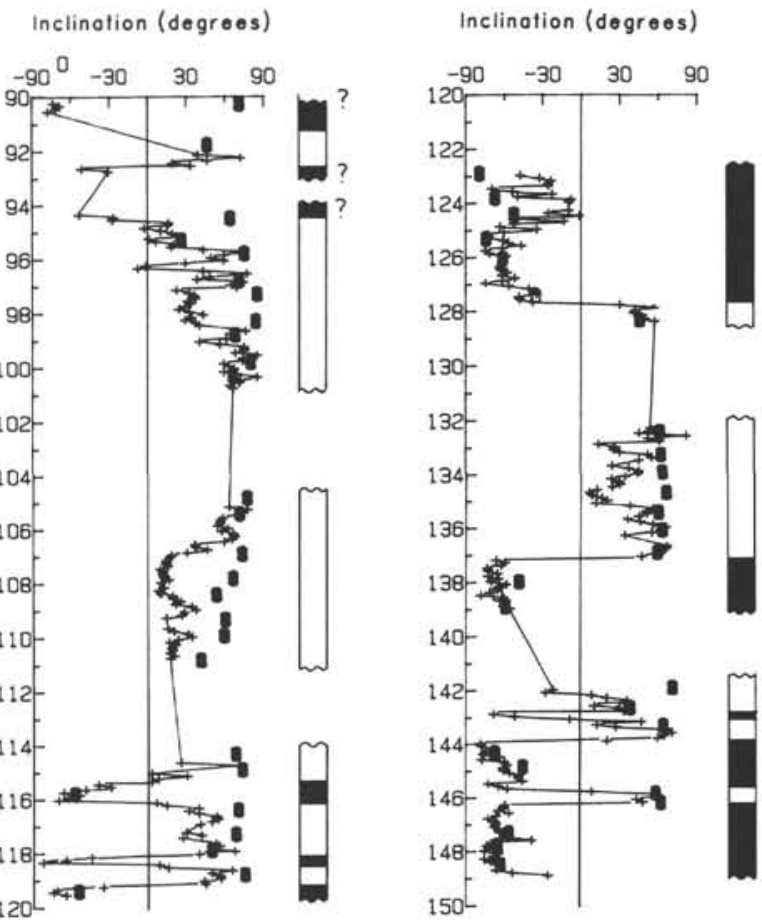

Figure 9 (continued).
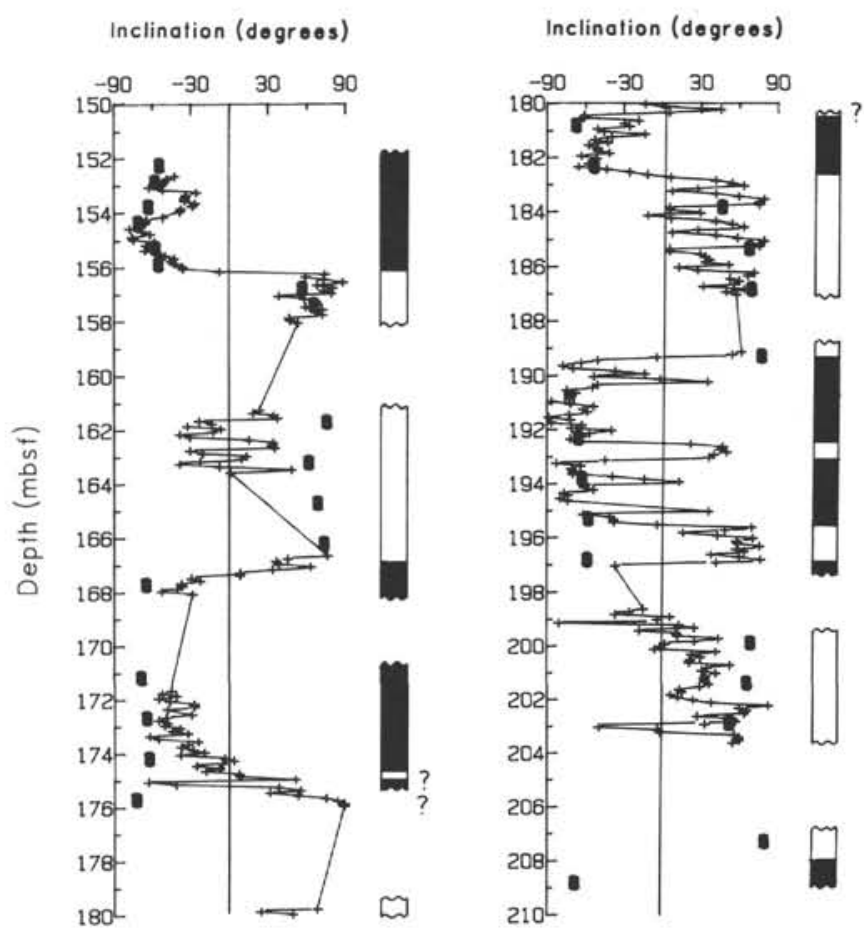

Figure 9 (continued).

alternative explanation is that the WCC data are less precise because they represent the average magnetization vector for the entire volume of sediment core within the magnetometer sensing region. In many cases this includes a thin layer of settled drilling slurry between the core and liner, which may have acquired a normal polarity remanent magnetization during core retrieval. Furthermore, drilling disturbance (particularly the downward bending of bedding planes) occurs 
Inclination (degrees)
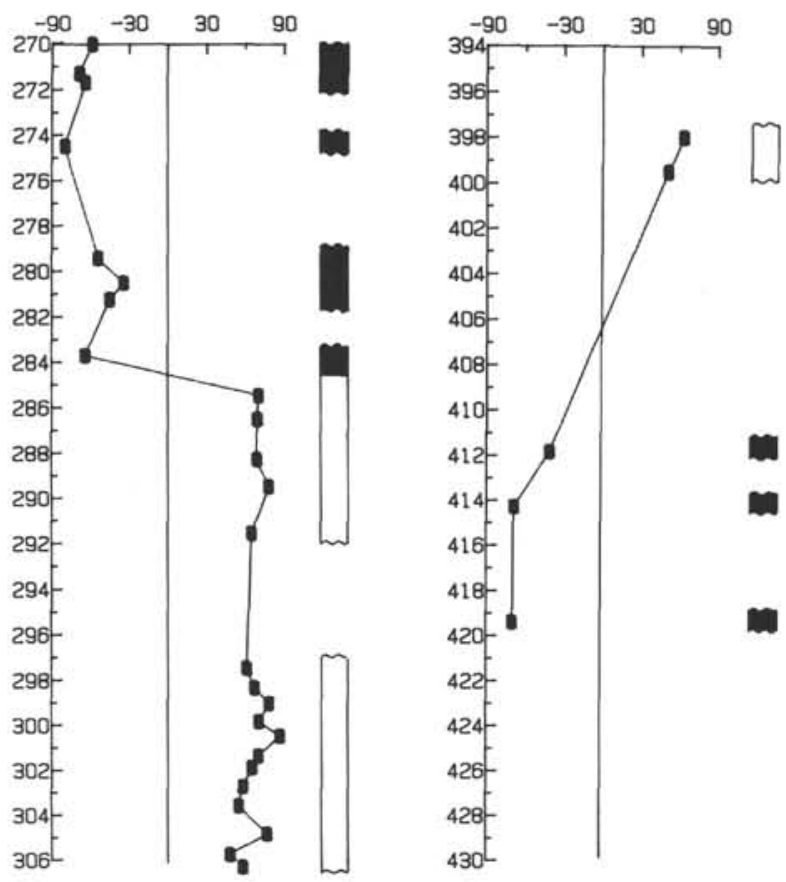

Figure 9 (continued).

preferentially at the margins of the core. This disturbed material will be included within the WCC sensing region, whereas discrete samples, taken from the central part of the core, will be less affected by such disturbance.

In some parts of the core (e.g., 161-163.5 mbsf) the WCC inclination values are too shallow and variable to yield meaningful polarity determinations. However, the DSC determinations for these intervals generally provide reliable results.

The combined WCC/DSC data set provides good definition of the succession of polarity reversals for most of the cored interval above $210 \mathrm{mbsf}$ in Hole 699A, with the exception of the interval from 74 to 90 mbsf (Core 114-699A-9H, not plotted in Fig. 9), which was affected by extensive drilling disturbance. Below 210 mbsf the record is more fragmentary. In particular, Cores 114-699A-24X to 114-699A-29X (214.6 to $268.6 \mathrm{mbsf}$ ) and $114-699 \mathrm{~A}-34 \mathrm{X}$ to $114-699 \mathrm{~A}-42 \mathrm{X}$ (306.6 to $392.1 \mathrm{mbsf}$ ) were badly disturbed, and no paleomagnetic data are available for these intervals.

\section{Hole 700B}

Because of downhole contamination from strongly magnetic seafloor rocks, it was not possible to acquire meaningful whole-core paleomagnetic data for the upper 276-m section (Cores 114-700B-1R to 114-700B-29R) of Hole 700B. However, this data gap is bridged, at least in part, by the paleomagnetic results from the 80 discrete samples taken from this interval (Fig. 10). Below $276 \mathrm{mbsf}$ the combined whole-core and discrete sample data set provides a fairly continuous record of the sequence of geomagnetic polarity reversals at this site throughout the Late Cretaceous and early Paleocene. With the exception of the depth interval from 304.5 to 314 mbsf (Core 114-700B$33 \mathrm{R})$, no data gap exceeds $6 \mathrm{~m}$.

As with the paleomagnetic data for Hole 699A, the Hole 700B WCC inclination values are usually shallower than the DSC values, with this effect more pronounced for reverse polarity than for normal polarity intervals.

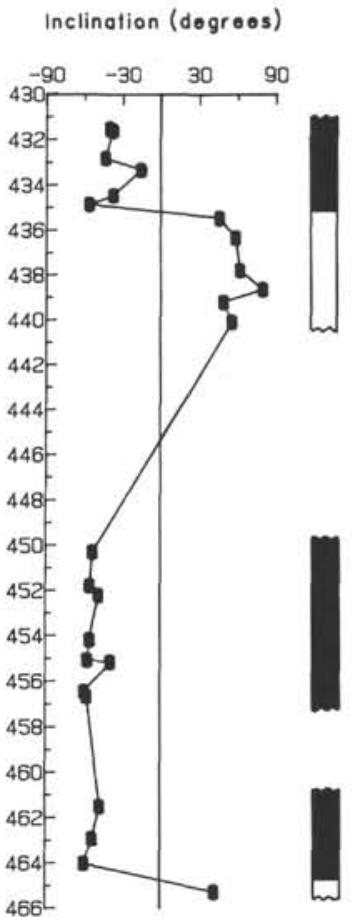

Figure 9 (continued).

\section{MAGNETIC STRATIGRAPHY}

\section{Hole 699A}

\section{Early Pliocene-Pleistocene}

The polarity reversal sequence identified in the early Pliocene to Pleistocene age sediments of Cores 114-699A-1H to $114-699 \mathrm{~A}-8 \mathrm{H}$ is shown in Figure 11, with the GPTS of Berggren et al. (1985) for this interval plotted across the top of the diagram. The paleomagnetically calibrated PleistocenePliocene diatom and radiolarian datums available for this site at the time of writing (Table 3) also are shown.

Correlation of the observed polarity reversal sequence in this interval to the GPTS is not straightforward, because of the limited resolution of the biostratigraphic data and because the diatom data indicate that sedimentary hiatuses may be present in the section in Cores 114-699A-2 H and 114-699A-5H, at depths of $\sim 11.2(\sim 0.77-1.14 \mathrm{Ma})$ and $\sim 45.27(\sim 4.19-4.65$ Ma) mbsf. The dominantly normal polarity magnetozone in Core 114-699A-1H appears to correlate with the Brunhes Chron, whilst the short normal polarity interval at the top of Core 114-699A-2H may represent either the early part of the Brunhes Chron or the Jaramillo Subchron. The distinct normal polarity magnetozone in the upper part of Core 114-699A$3 \mathrm{H}$ can be correlated with confidence to the Olduvai Subchron, and a record of the Gauss/Matuyama Chron boundary is tentatively identified in the upper part of Core 114-699A$4 \mathrm{H}$, at a depth of about 29.5 mbsf.

Correlation of the polarity sequence observed below $30 \mathrm{mbsf}$ with the GPTS becomes increasingly difficult with depth because of the possible presence of hiatuses. The simplest interpretation of this sequence links the dominantly normal polarity interval in the depth range from 29.5 to 40.7 mbsf to the Gauss Chron, the reverse polarity interval from 40.7 to $53.6 \mathrm{mbsf}$ to the Gilbert Chron, and the N-R-N sequence in the interval from 53.6 to 62.4 mbsf to Chron C3AN, as indicated in Figure 11. However, it must be emphasized that this interpretation is poorly constrained 


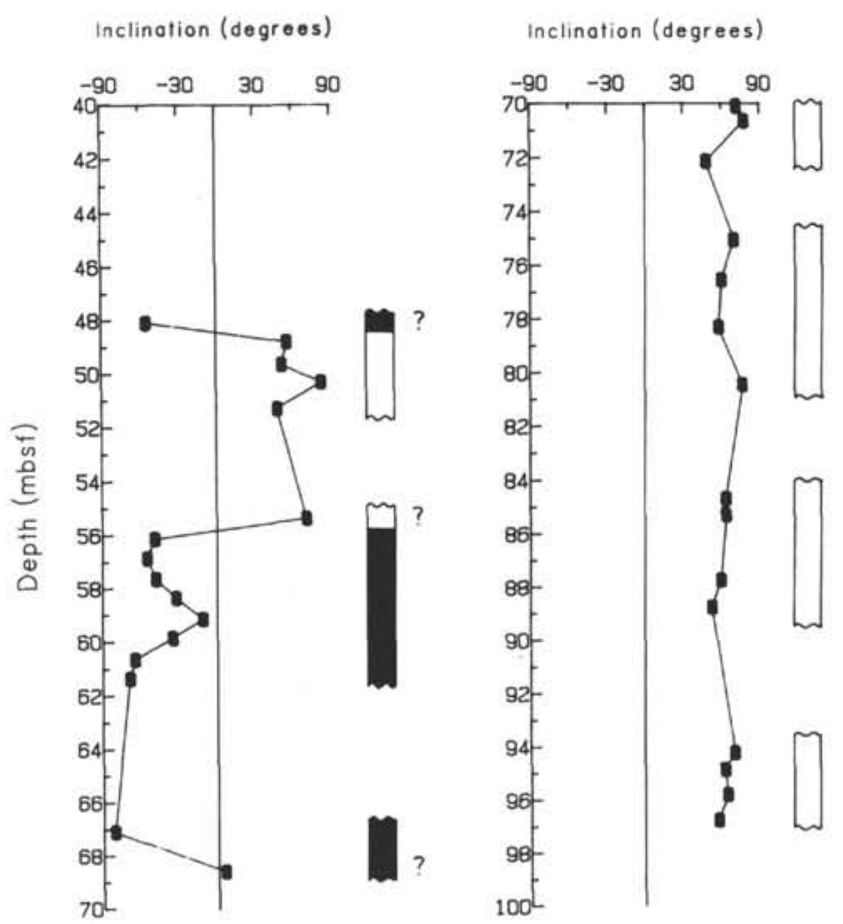

Figure 10. Variation of inclination of remanent magnetization and inferred magnetic polarity with depth in Hole 700B. Symbols and conventions as in Figure 9. As a result of core disturbance, no data are available for the intervals 100-110, 198-246, and 306-314 mbsf.
Inclination (degrees)

Inclinotion (degrees)

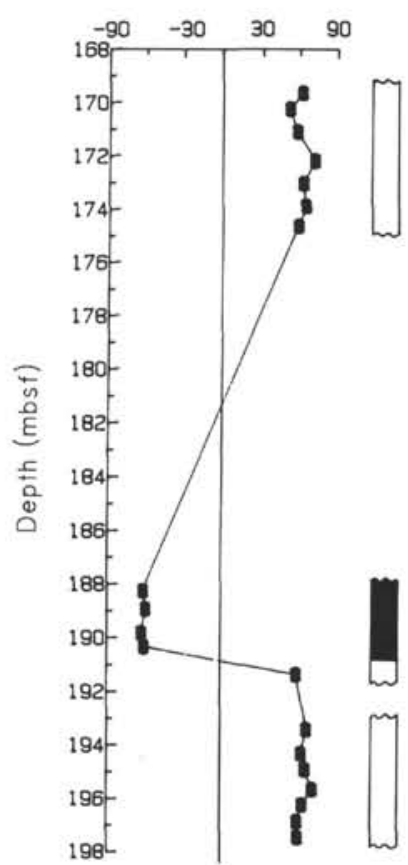

Figure 10 (continued).

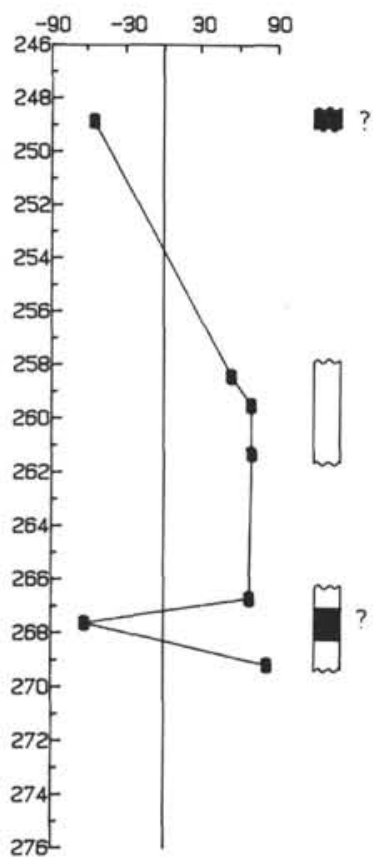

$$
\text { . }
$$




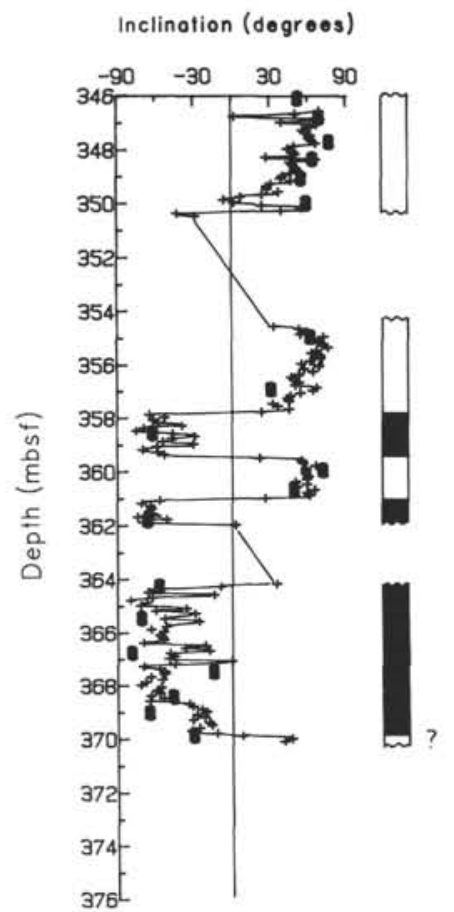

Figure 10 (continued).
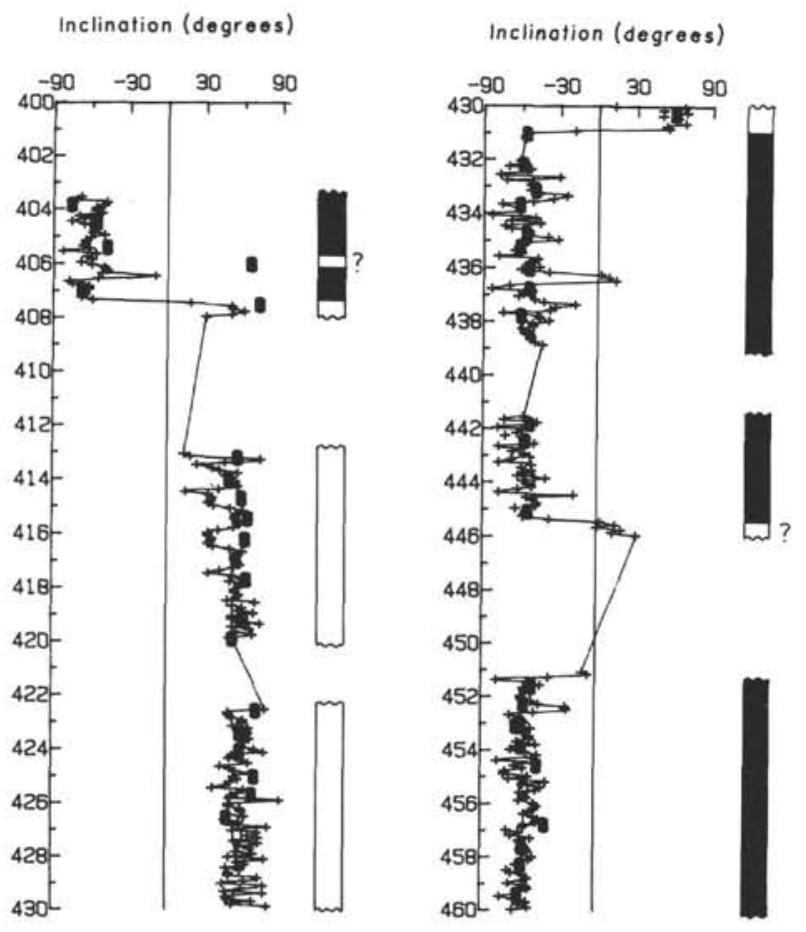

Figure 10 (continued).

and may require revision if the possible presence of the hiatuses in Cores $114-699 \mathrm{~A}-4 \mathrm{H}$ and $114-699 \mathrm{~A}-5 \mathrm{H}$ is substantiated by further biostratigraphic studies.

\section{Oligocene}

A particularly notable feature of Hole 699A is the recovery of a thick sequence of Oligocene sediments in Cores

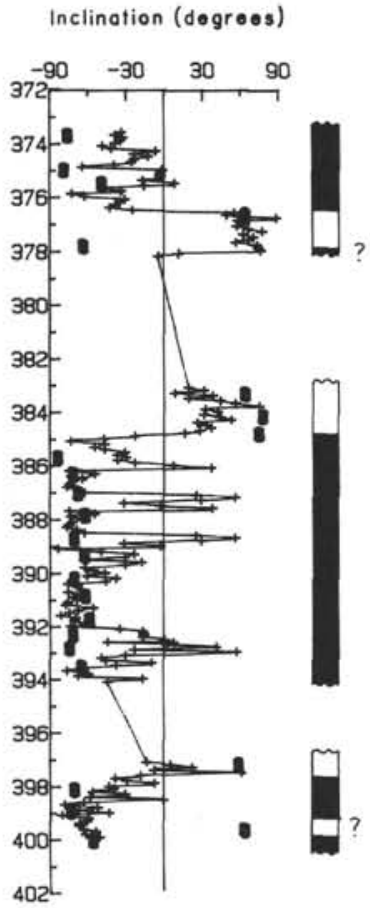

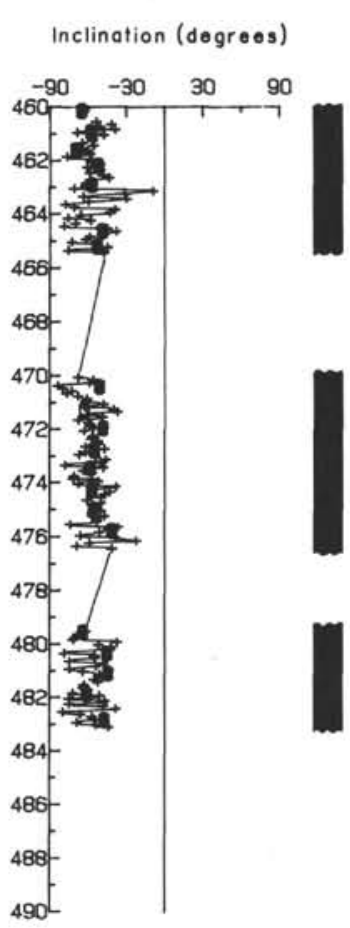

Figure 10 (continued).

Table 1. Polarity transitions, Hole 699A.

\begin{tabular}{cc}
\hline $\begin{array}{c}\text { Depth and range } \\
\text { (mbsf) }\end{array}$ & $\begin{array}{c}\text { Downward } \\
\text { change in } \\
\text { polarity }\end{array}$ \\
\hline $10.59 \pm 0.15$ & N-R \\
$19.59 \pm 0.25$ & R-N \\
$21.19 \pm 0.05$ & N-R \\
$29.45 \pm 0.30$ & R-N \\
$40.69 \pm 0.15$ & N-R \\
$43.99 \pm 0.05(?)$ & R-N \\
$53.61 \pm 0.53$ & R-N \\
$58.01 \pm 0.07$ & N-R \\
$60.86 \pm 0.21$ & R-N \\
$62.39 \pm 0.05$ & N-R \\
$68.84 \pm 0.10$ & N-R \\
$70.29 \pm 0.05$ & R-N \\
$87.57 \pm 0.27$ & R-N \\
$91.17 \pm 0.63$ & N-R \\
$92.49 \pm 0.15$ & R-N \\
$94.47 \pm 0.03$ & N-R \\
$115.35 \pm 0.45$ & R-N \\
$116.22 \pm 0.18$ & N-R \\
$118.09 \pm 0.05$ & R-N \\
$118.49 \pm 0.15$ & N-R \\
$119.24 \pm 0.10$ & R-N \\
&
\end{tabular}

\begin{tabular}{cc}
\hline $\begin{array}{c}\text { Depth and range } \\
\text { (mbsf) }\end{array}$ & $\begin{array}{c}\text { Downward } \\
\text { change in } \\
\text { polarity }\end{array}$ \\
\hline $127.69 \pm 0.15$ & N-R \\
$137.09 \pm 0.05$ & R-N \\
$142.74 \pm 0.10$ & R-N \\
$143.05 \pm 0.10$ & N-R \\
$143.84 \pm 0.10$ & R-N \\
$145.73 \pm 0.08$ & N-R \\
$146.21 \pm 0.04$ & R-N \\
$156.14 \pm 0.10$ & N-R \\
$166.95 \pm 0.75$ & R-N \\
$182.69 \pm 0.35$ & N-R \\
$189.34 \pm 0.10$ & R-N \\
$192.55 \pm 0.10$ & N-R \\
$193.05 \pm 0.10$ & R-N \\
$195.55 \pm 0.10$ & N-R \\
$197.00 \pm 0.05$ & R-N \\
$198.35 \pm 1.55$ & N-R \\
$208.09 \pm 0.25$ & R-N \\
$216.05 \pm 0.75$ & N-R \\
$284.55 \pm 0.86$ & N-R \\
$434.68 \pm 0.20$ & N-R \\
$464.65 \pm 0.63$ & N-R \\
\hline
\end{tabular}

Note: Transitions interpolated within coring or sampling gaps can be identified from the associated large range of uncertainty. Boundaries of thin or otherwise poorly defined polarity intervals are indicated by a query.

114-699A-10H to 114-699A-27X. This sequence provides an important opportunity for calibrating Oligocene high-latitude biostratigraphic zonations, particularly key nannofossil, diatom, and radiolarian datums, against the GPTS.

The magnetostratigraphic sequence observed in these cores is plotted against the GPTS of Berggren et al. (1985) in 
Table 2. Polarity transitions, Hole 700B.

\begin{tabular}{lc}
\hline $\begin{array}{c}\text { Depth and range } \\
\text { (mbsf) }\end{array}$ & $\begin{array}{c}\text { Downward } \\
\text { change in polarity }\end{array}$ \\
\hline $48.45 \pm 0.35(?)$ & N-R \\
$55.76 \pm 0.39(?)$ & R-N \\
$68.60 \pm 1.50$ & N-R \\
$152.01 \pm 0.47$ & R-N \\
$164.16 \pm 5.51$ & N-R \\
$190.86 \pm 0.52$ & N-R \\
$267.19 \pm 0.45(?)$ & R-N \\
$268.42 \pm 0.78(?)$ & N-R \\
$299.13 \pm 0.13$ & R-N \\
$314.76 \pm 0.20$ & N-R \\
$315.16 \pm 0.10$ & R-N \\
$316.76 \pm 0.10$ & N-R \\
$316.96 \pm 0.10$ & R-N \\
$318.16 \pm 0.10$ & N-R \\
\hline
\end{tabular}

\begin{tabular}{lc}
\hline $\begin{array}{c}\text { Depth and range } \\
\text { (mbsf) }\end{array}$ & $\begin{array}{c}\text { Downward } \\
\text { change in polarity }\end{array}$ \\
\hline $318.84 \pm 0.38$ & R-N \\
$327.31 \pm 0.16$ & R-N \\
$333.29 \pm 0.04$ & N-R \\
$337.72 \pm 0.62$ & R-N \\
$344.22 \pm 1.92$ & N-R \\
$357.75 \pm 0.10$ & R-N \\
$359.45 \pm 0.10$ & N-R \\
$360.95 \pm 0.10$ & R-N \\
$369.80 \pm 0.15(?)$ & N-R \\
$376.45 \pm 0.10$ & N-R \\
$384.82 \pm 0.14$ & R-N \\
$397.64 \pm 0.46$ & R-N \\
$407.45 \pm 0.10$ & N-R \\
$430.95 \pm 0.10$ & R-N \\
\hline
\end{tabular}

Note: Transitions interpolated within coring or sampling gaps can be identified from the associated large range of uncertainty. Boundaries of thin or otherwise poorly defined polarity intervals are indicated by a query.

Figure 12. Unfortunately, few age-calibrated biostratigraphic datums are available at the time of writing to constrain the correlation of these two data sets. The only available data are the two nannofossil datums and one diatom datum shown in Figure 12. The youngest of these, the top of the Reticulofenestra bisecta Zone, occurs in the lower part of Core 114-699A-11H (Shipboard Scientific Party, 1988). This datum has been assigned an age of $23.7 \mathrm{Ma}$ by Wise (1983) and Berggren et al. (1985), but J. Backman (pers. comm., 1988) believes that it may be significantly older.

The second nannofossil datum, the top of the Chiasmolithus altus Zone, has been identified in the upper part of Core 114-699A-15H (Shipboard Scientific Party, 1988). Unfortunately, the possible age range of this datum, 23.7 to $28.1 \mathrm{Ma}$ (Martini and Müller, 1986; Berggren et al., 1985), is too large for it to be of much value in constraining the calibration of the Hole 699A magnetic zonations. However, the important firstappearance datum (FAD) of the diatom Rocella gelida, with an estimated age of $26 \mathrm{Ma}$ (Gombos and Ciesielski, 1983; Fenner, 1984), has been identified between Sections 114$699 \mathrm{~A}-14 \mathrm{H}-\mathrm{CC}$ and 114-699A-15H-CC (table 3, p. 167, of Shipboard Scientific Party, 1988). This suggests that the reverse magnetozone in the lower part of Core $114-699 \mathrm{~A}-14 \mathrm{H}$ and the upper part of Core 114-699A-15H represents Chron C7R. No other specific biostratigraphic tie-point is available from Cores 114-699A-10H to 114-699A-23X, but the top of early Oligocene nannofossil Zone NP22 (early Chron C12R) has been identified in Core 114-699A-27X. Thus, the normal polarity zone in Core 114-699A-23X must represent part or all of either Chron $\mathrm{C} 12 \mathrm{~N}$ or $\mathrm{C} 11 \mathrm{~N}$. The latter assignment is preferred, because the distinctive polarity signature of Cores $114-699 \mathrm{~A}-22 \mathrm{H}$ to $114-699 \mathrm{~A}-20 \mathrm{H}$ then provides a good correlation with Chrons $\mathrm{C} 10 \mathrm{R}$ to $\mathrm{C} 9 \mathrm{R}$ inclusive.

\section{Eocene}

The magnetostratigraphic record for the early Oligocene to early Eocene age sediments of Cores 114-699A-27X to 114$699 \mathrm{~A}-50 \mathrm{X}$ is discontinuous (Fig. 13). However, the available foraminiferal and nannofossil datums do provide some constraints on the interpretation of the observed magnetozones. Within these constraints the normal magnetozone in Cores 114-699A-30X and 114-699A-31X can be assigned to Chron $\mathrm{C} 13 \mathrm{~N}$, and the underlying long reverse magnetozone extend-
Table 3. Pleistocene-Pliocene biostratigraphic datums, Hole 699A (Shipboard Scientific Party, 1988).

\begin{tabular}{llll}
\hline Code $^{\text {a }}$ & \multicolumn{1}{c}{$\begin{array}{c}\text { batum } \\
\text { b }\end{array}$} & $\begin{array}{c}\text { Depth range } \\
\text { (mbsf) }\end{array}$ \\
\hline 1 & LAD Hemidiscus karstenii (D) & 0.195 & $0.02-0.40$ \\
2 & LAD Stylatractus universus (R) & 0.40 & $0.00-8.66$ \\
3 & LAD Saturnalis circularis (R) & 0.70 & $18.10-27.60$ \\
4 & LAD Coscinodiscus kolbei (D) & 1.89 & $21.70-23.70$ \\
5 & LAD Coscinodiscus vulnificus (D) & 2.20 & $27.60-28.84$ \\
6 & LAD Coscinodiscus insignus (D) & 2.49 & $30.53-31.00$ \\
7 & LAD Nitzschia weaveri (D) & 2.64 & $31.00-32.20$ \\
8 & LAD Nitzschia interfrigidaria (D) & 2.81 & $31.00-32.20$ \\
9 & LAD Helotholus vema (R) & 2.43 & $27.60-37.10$ \\
10 & LAD Desmospyris spongiosa (R) & 2.43 & $27.60-37.10$ \\
11 & First concurrent Coscinodiscus insignus & 3.10 & $39.03-40.37$ \\
& and Coscinodiscus vulnificus (D) & & \\
12 & FAD Nitzschia weaveri (D) & 3.88 & $39.03-40.37$ \\
13 & LAD Prunopyle titan (R) & 3.20 & $37.10-46.60$ \\
14 & FAD Nitzschia interfrigidaria (D) & 4.02 & $42.03-43.60$ \\
15 & FAD Nitzschia angulata (D) & 4.22 & $46.60-46.63$ \\
16 & LAD Denticulopsis hustedtii (D) & 4.48 & $47.02-48.16$ \\
17 & LAD Amphomerium challengerae (R) & 4.35 & $46.60-56.10$ \\
18 & FAD Nitzschia reinholdii (D) & 6.50 & $54.53-58.04$ \\
19 & LAD Stichocorys peregrina (R) & 4.50 & $56.10-65.60$ \\
\hline & & &
\end{tabular}

${ }_{\mathrm{b}}^{\mathrm{a}}$ Plotted by code in Figure 11.

$\mathrm{FAD}=$ first-appearance datum; $\mathrm{LAD}=$ last-appearance datum; $\mathrm{D}=$ diatom; $\mathrm{R}=$ radiolarian.

ing from the lower part of Core 114-699A-31X to the base of Core 114-699A-33X to Chron C13R. Similarly, the observed R-N-R-N-R sequence in Cores 114-699A-43X to 114-699A$50 \mathrm{X}$ can be correlated with Chrons C20R to C22R.

The paleomagnetic datums defined for Hole 699A are summarized in Table 4.

\section{Hole 700B}

The sequence of magnetozones observed in the middle Eocene to Late Cretaceous age nannofossil chalks and limestones of Hole 700B is plotted against the corresponding part of the GPTS of Berggren et al. (1985) in Figure 14. The calcareous nannofossil and foraminifer datums identified for this hole (Table 5) permit the succession of magnetozones beneath 275 mbsf to be confidently correlated to the GPTS. Above this depth the magnetostratigraphic data are less continuous, but a tentative correlation of each of the observed polarity transitions can be made.

In the upper part of Hole 700B the observed polarity sequence in the depth interval 48 to $97 \mathrm{mbsf}$ can be correlated either with Chron sequence early $\mathrm{C} 18 \mathrm{~N}$ to $\mathrm{C} 19 \mathrm{R}$ or with early $\mathrm{C} 19 \mathrm{~N}$ to $\mathrm{C} 20 \mathrm{R}$. Although the former solution is more compatible with biostratigraphic datum 2 (the last-appearance datum of Acarinina bullbrooki, Table 5), this correlation requires a very rapid sediment-accumulation rate $(>50 \mathrm{~m} / \mathrm{m} . y$.) to account for the length of the reverse polarity magnetozone in the depth interval 69 to 97 mbsf. The alternative correlation provides better agreement with the pair of biostratigraphic datums 3 and 4 (FAD Globogerinatheka index and FAD Nannotetrina fulgens, Table 5) and also implies a more uniform sedimentation rate throughout the middle Eocene.

Although the magnetozones identified from the isolated groups of magnetic polarity determinations in the depth range from 100 to 255 mbsf are poorly defined, the biostratigraphic data for this interval indicate that the observed 


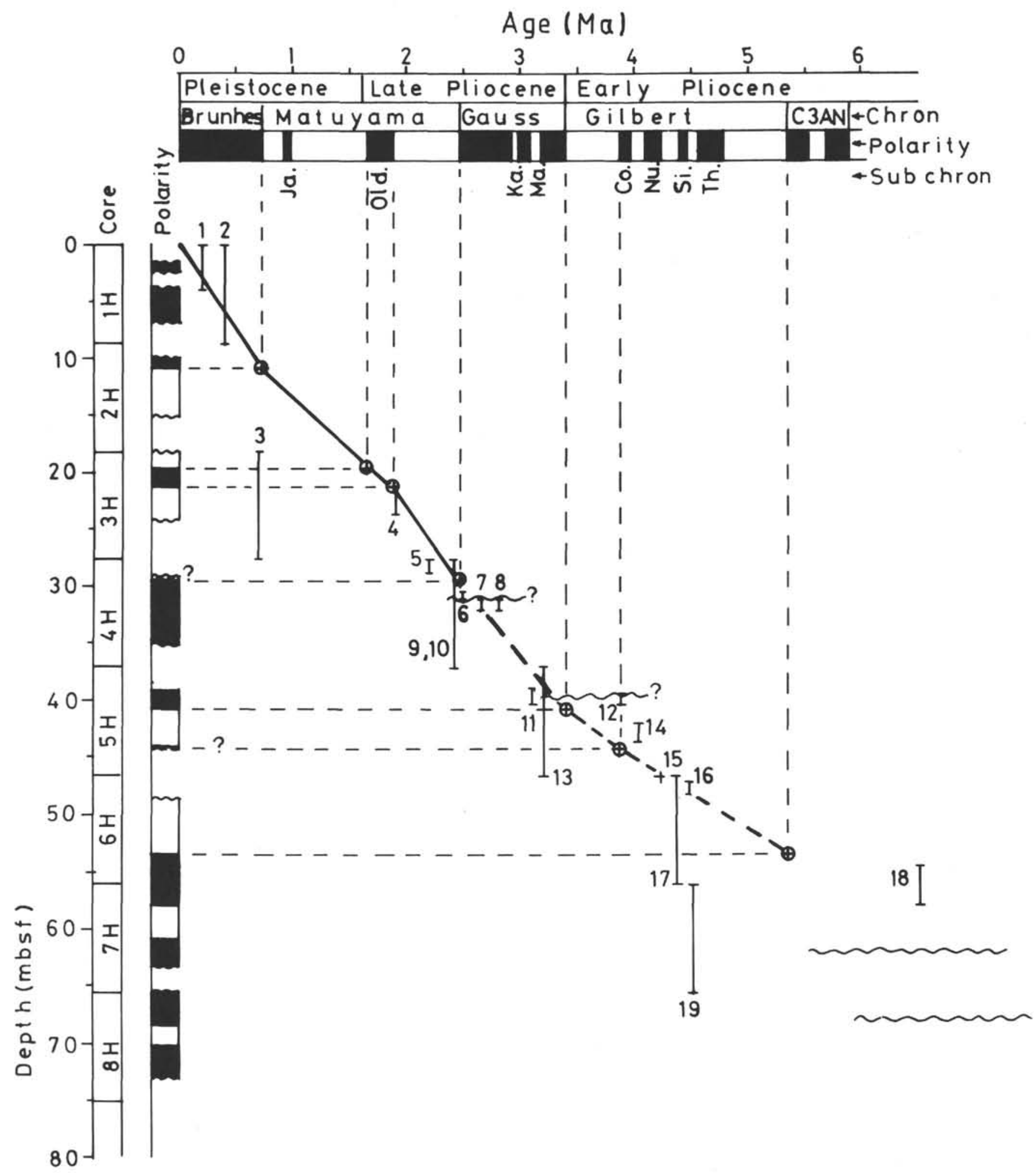

Figure 11. Correlation of the magnetic polarity reversal record in the Pleistocene-Pliocene sequence of Hole 699A to the GPTS of Berggren et al. (1985). The numbered biostratigraphic datums are listed in Table 3. 
Table 4. Paleomagnetic datums, Hole 699A.

\begin{tabular}{|c|c|c|c|c|}
\hline Paleomagnetic datum & $\begin{array}{l}\text { Age } \\
(\mathrm{Ma})\end{array}$ & $\begin{array}{l}\text { Bracketing samples (core, } \\
\text { section, interval in } \mathrm{cm} \text { ) }\end{array}$ & Depth range (mbsf) & Mean depth (mbsf) \\
\hline Brunhes/Matuyama & 0.73 & $2 \mathrm{H}-2,34$, to $2 \mathrm{H}-2,64$ & $10.44-10.74$ & $10.59 \pm 0.15$ \\
\hline Matuyama/ Olduvai & 1.66 & $3 \mathrm{H}-1,124$, to $3 \mathrm{H}-2,24$ & $19.34-19.84$ & $19.59 \pm 0.25$ \\
\hline Olduvai/ Matuyama & 1.88 & $3 \mathrm{H}-3,4$, to $3 \mathrm{H}-3,14$ & $21.14-21.24$ & $21.19 \pm 0.05$ \\
\hline Matuyama/ Gauss & 2.47 & $4 \mathrm{H}-2,5$, to $4 \mathrm{H}-2,65$ & $29.15-29.75$ & $29.45 \pm 0.30$ \\
\hline Gauss/Gilbert & 3.40 & $5 \mathrm{H}-3,75$, to $5 \mathrm{H}-3,45$ & $40.84-40.54$ & $40.69 \pm 0.15$ \\
\hline Gauss/C3AN & 5.35 & $6 \mathrm{H} 6,4$, to $6 \mathrm{H}-5,49$ & $54.14-53.08$ & $53.61 \pm 0.53$ \\
\hline a $66 \mathrm{BR} / \mathrm{C} 6 \mathrm{CN}$ & 23.27 & $10 \mathrm{H}-2,121$, to $10 \mathrm{H}-3,25$ & $87.30-87.84$ & $87.57 \pm 0.27$ \\
\hline $\mathrm{C} 6 \mathrm{CN} / \mathrm{C} 6 \mathrm{CR}$ & 24.21 & $11 \mathrm{H}-1,35$, to $11 \mathrm{H}-1,41$ & $94.44-94.50$ & $94.47 \pm 0.03$ \\
\hline C6CR/C7N & 25.50 & $13 \mathrm{H}-2,31$, to $13 \mathrm{H}-2,121$ & $114.90-115.80$ & $115.35 \pm 0.45$ \\
\hline C7N/C7R & 25.97 & $14 \mathrm{H}-4,44$, to $14 \mathrm{H}-4,74$ & $127.54-127.84$ & $127.69 \pm 0.15$ \\
\hline C7R/C7AN & 26.38 & $15 \mathrm{H}-4,44$, to $15 \mathrm{H}-4,54$ & $137.04-137.14$ & $137.09 \pm 0.05$ \\
\hline C7AN/C7AR & 26.56 & $15 \mathrm{H}-5,79$, to $16 \mathrm{H}-1,29$ & $138.88-141.88$ & $140.38 \pm 1.50$ \\
\hline C7AR/C8N & 26.86 & $16 \mathrm{H}-2,64$, to $16 \mathrm{H}-2,84$ & $143.74-143.94$ & $143.84 \pm 0.10$ \\
\hline $\mathrm{C} 8 \mathrm{~N} / \mathrm{C} 8 \mathrm{R}$ & 27.74 & $17 \mathrm{H}-4,44$, to $17 \mathrm{H}-4,64$ & $156.04-156.24$ & $156.14 \pm 0.10$ \\
\hline $\mathrm{C} 8 \mathrm{R} / \mathrm{C} 9 \mathrm{~N}$ & 28.15 & $18 \mathrm{H}-4,111$, to $18 \mathrm{H}-5,111$ & $166.20-167.70$ & $166.95 \pm 0.75$ \\
\hline $\mathrm{C} 9 \mathrm{~N} / \mathrm{C} 9 \mathrm{R}$ & 29.21 & $20 \mathrm{H}-2,124$, to $20 \mathrm{H}-3,44$ & $182.34-183.04$ & $182.69 \pm 0.35$ \\
\hline $\mathrm{C} 9 \mathrm{R} / \mathrm{C} 10 \mathrm{~N}$ & 29.73 & $21 \mathrm{H}-1,14$, to $21 \mathrm{H}-1,34$ & $189.24-189.44$ & $189.34 \pm 0.10$ \\
\hline $\mathrm{C} 10 \mathrm{~N} / \mathrm{ClOR}$ & 30.33 & $21 \mathrm{H}-6,21$, to $22 \mathrm{H}-1,131$ & $196.80-199.90$ & $198.35 \pm 1.55$ \\
\hline $\mathrm{ClOR} / \mathrm{C} 11 \mathrm{~N}$ & 31.23 & $23 X-2,124$, to $23 X-3,24$ & $207.84-208.34$ & $208.09 \pm 0.25$ \\
\hline $\mathrm{C} 11 \mathrm{~N} / \mathrm{C} 11 \mathrm{R}$ & 32.06 & $24 \mathrm{X}-1,71$, to $24 \mathrm{X}-2,71$ & $215.30-216.80$ & $216.05 \pm 0.75$ \\
\hline $\mathrm{C} 13 \mathrm{~N} / \mathrm{C} 13 \mathrm{R}(?)$ & 35.87 & $31 X-4,110$, to $31 X-5,132$ & $283.69-285.41$ & $284.55 \pm 0.86$ \\
\hline $\mathrm{C} 20 \mathrm{R} / \mathrm{C} 21 \mathrm{~N}(?)$ & 48.75 & $43 X-5,140$, to $45 X-1,73$ & $399.49-411.82$ & $405.65 \pm 6.16$ \\
\hline $\mathrm{C} 21 \mathrm{~N} / \mathrm{C} 21 \mathrm{R}(?)$ & 50.34 & $47 X-3,139$, to $47 X-4,29$ & $434.48-434.88$ & $434.68 \pm 0.20$ \\
\hline $\mathrm{C} 21 \mathrm{R} / \mathrm{C} 22 \mathrm{~N}(?)$ & 51.95 & $48 \mathrm{X}-1,53$, to $49 \mathrm{X}-1,122$ & $440.12-450.31$ & $445.21 \pm 5.09$ \\
\hline $\mathrm{C} 22 \mathrm{~N} / \mathrm{C} 22 \mathrm{R}(?)$ & 52.62 & $50 X-4,93$, to $50 X-5,69$ & $464.02-465.28$ & $464.65 \pm 0.63$ \\
\hline
\end{tabular}

Truncated by hiatus, therefore older than $23.27 \mathrm{Ma}$.

$\mathrm{R}-\mathrm{N}-\mathrm{R}-\mathrm{N}-\mathrm{R}$ sequence in the depth range 150 to $198 \mathrm{mbsf}$ probably represents the Chron sequence C21R-C22N-C22R$\mathrm{C} 23 \mathrm{~N}-\mathrm{C} 23 \mathrm{R}$. The set of late Paleocene and early Paleocene biostratigraphic datums in the depth range 270 to $300 \mathrm{mbsf}$ indicates that the long reverse polarity interval in Cores 114-700B-29R to 114-700B-31R correlates with Chron C26R. Chron $\mathrm{C} 27 \mathrm{~N}$ is represented by the normal polarity magnetozone in the lower part of Core 114-700B-32R. A record of Chron C27R appears to be missing, because of the poor recovery in Core 114-700B-33R, but Chrons C28N and C28R are each partially represented in Cores $114-700 \mathrm{~B}-35 \mathrm{R}$ and 114-700B-36R.

Beneath 325 mbsf, in Cores 114-700B-36R to 114-700B$54 \mathrm{R}$, the observed sequence of magnetozones shows a good correspondence with the sequence of polarity reversals between Chrons C29N and C34N. The available nannofossil data suggest that a significant hiatus may span the Cretaceous/ Tertiary boundary in this hole (Crux, this volume). However it is now well established that the Cretaceous/Tertiary boundary lies within Chron C29R (e.g., Lowrie and Alvarez, 1981; Butler and Lindsay, 1985). There is evidence from the WCC data for a short reverse polarity interval in the lower part of Core 114-700B-37R ( $\sim 333.2$ to $333.8 \mathrm{mbsf})$ and in the upper part of Core 114-700B-38R ( $\sim 336.8$ to $337.2 \mathrm{mbsf})$. The latter interval is defined also by a single DSC determination (Fig. 10). Reliable paleomagnetic data are not available for the intervening short interval, but the total thickness is comparable to that expected for Chron C29R if the sedimentation rate remained approximately uniform over this interval (Fig. 14). This suggests that sedimentation probably was continuous over the Cretaceous/Tertiary boundary at Site 700 and that the hiatus exists instead within the anomalously short normal polarity magnetozone of Core $114-700 \mathrm{~B}-38 \mathrm{R}$, which is assigned to Chron $\mathrm{C} 30 \mathrm{~N}$.

\section{CONCLUSIONS}

Paleomagnetic investigations of the Cenozoic and late Mesozoic age sediments recovered at ODP Sites 699 and 700 indicate the presence of a well-defined characteristic component of stable remanent magnetization in the vast majority of samples analyzed. In most cases, magnetically "soft" components of remanence acquired at the drill site or in the laboratory are effectively removed by AF demagnetization in applied fields of 5 to $10 \mathrm{mT}$. There is evidence for a small $\left(\sim 10^{\circ}\right)$ modification of the direction of this stable remanence during storage and drying out of these sediments in the laboratory over a period of several months. However, this does not affect the reliability of the magnetic polarity determinations.

High-quality magnetostratigraphic data, which can be reliably correlated with the GPTS of Berggren et al. (1985), were obtained for the Oligocene and late Pliocene to Pleistocene age sequences recovered from Hole $699 \mathrm{~A}$ and the Late Cretaceous to Paleocene age sediments recovered from Hole 700B. The magnetostratigraphic record from the Eocene sediments recovered at both sites is more fragmentary, because of extensive drilling disturbance, but the available biostratigraphic data do permit chronal assignments to be made for some parts of the Eocene sections. The paleomagnetic datums identified for the two sites are listed in Tables 4 and 6.

\section{ACKNOWLEDGMENTS}

We would like to express our appreciation to the many people who have contributed to the success of this work. 
Table 5. Middle Eocene-Late Cretaceous biostratigraphic datums, Hole 699A.

\begin{tabular}{|c|c|c|c|}
\hline $\operatorname{Code}^{\mathrm{a}}$ & Datum $^{\text {b }}$ & $\begin{array}{l}\text { Age } \\
(\mathrm{Ma})\end{array}$ & $\begin{array}{l}\text { Depth range } \\
\text { (mbsf) }\end{array}$ \\
\hline 1 & LAD Chiasmolithus solitus $(\mathbb{N})$ & 42.30 & $26.40-26.99$ \\
\hline 2 & LAD Acarinina bullbrooki (F) & 43.00 & $57.57-58.65$ \\
\hline$c^{3}$ & FAD Globigerinatheka index $(\mathrm{F})$ & 45.00 & $70.67-72.17$ \\
\hline $\mathrm{c}_{4}$ & FAD Nannotetrina fulgens $(\mathbb{N})$ & 49.80 & $102.94-112.12$ \\
\hline 5 & FAD Discoaster sublodoensis $(\mathrm{N})$ & 52.60 & $158.99-169.70$ \\
\hline 6 & LAD Tribrachiatus orthostylus $(\mathrm{N})$ & 53.70 & $175.10-190.46$ \\
\hline 7 & LAD Fasciculithus tympaniformis (N) & 57.60 & $219.28-238.40$ \\
\hline 8 & LAD Acarinina velascoensis $(\mathrm{F})$ & 57.80 & $219.28-239.30$ \\
\hline 9 & FAD Discoaster multiradiatus $(\mathrm{N})$ & 59.20 & $242.44-247.80$ \\
\hline 10 & FAD Acarinina velascoensis $(\mathrm{F})$ & 61.70 & $261.04-262.52$ \\
\hline 11 & FAD Heliolithus riedelii $(\mathrm{N})$ & 60.00 & $269.22-269.57$ \\
\hline 12 & LAD Planorotalites pseudomenardii (F) & 58.80 & $269.57-276.48$ \\
\hline 13 & FAD Heliolithus kleinpellii $(\mathbb{N})$ & 61.60 & $269.57-278.70$ \\
\hline 14 & LAD "Subbotina" pseudobulloides (F) & 61.70 & $278.83-280.30$ \\
\hline 15 & FAD Planorotalites pseudomenardii $(\mathrm{F})$ & 61.00 & $281.82-283.30$ \\
\hline 16 & FAD Morozovella pusilla (F) & 62.00 & $286.93-288.40$ \\
\hline 17 & FAD Morozovella angulata $(\mathrm{F})$ & 62.30 & $286.92-292.90$ \\
\hline$c^{18}$ & LAD Globoconusa daubjergensis (F) & 64.00 & $289.87-291.40$ \\
\hline 19 & LAD Fasciculithus tympaniformis $(\mathrm{N})$ & 62.00 & $292.66-295.00$ \\
\hline 20 & FAD "Morozovella" uncinata $(\mathrm{F})$ & 63.00 & 299.87-301.01 \\
\hline 21 & FAD "Morozovella" trinidadensis $(\mathrm{F})$ & 64.50 & $302.82-303.30$ \\
\hline 22 & FAD Planorotalites compressus $(\mathrm{F})$ & 64.50 & $316.25-317.73$ \\
\hline 23 & FAD Subbotina pseudobulloides (F) & 66.10 & $328.20-329.81$ \\
\hline 24 & FAD Chiasmolithus daniscus $(\mathrm{N})$ & 64.80 & $329.81-331.70$ \\
\hline 25 & FAD Cruciplacolithus tenuis $(\mathrm{N})$ & 65.90 & $329.81-331.70$ \\
\hline 26 & FAD Placozygus sigmoides $(\mathrm{N})$ & 66.40 & $329.81-331.70$ \\
\hline 27 & FAD Globoconusa daubjergensis (F) & 66.35 & $329.81-331.70$ \\
\hline 28 & FAD Planorotalites cf. eugubinus (F) & 66.35 & $329.81-331.70$ \\
\hline 29 & LAD Nephrolithus frequens $(\mathrm{N})$ & 66.40 & $329.81-332.51$ \\
\hline 30 & FAD Abathomphalus mayaroensis (F) & 70.45 & $350.26-355.18$ \\
\hline$c^{31}$ & FAD Broinsonia parca $(\mathrm{N})$ & 84.00 & $420.08-431.52$ \\
\hline 32 & LAD Marginotruncana marginata (F) & 84.00 & $445.70-439.21$ \\
\hline$c^{33}$ & LAAD Marginotruncana $(\mathrm{F})$ & 84.00 & $445.70-451.00$ \\
\hline$c^{34}$ & LAD Dicarinella hagni $(\mathrm{F})$ & 88.50 & $480.21-481.98$ \\
\hline 35 & FAD Micula staurophora $(\mathrm{N})$ & 90.00 & $>483.86$ \\
\hline
\end{tabular}

${ }_{b}^{\text {a }}$ Plotted by code in Figure 14.

$\mathrm{FAD}=$ first-appearance datum; $\mathrm{LAD}=$ last-appearance datum; $\mathrm{LAAD}=$ last absolute appearance datum; $\mathrm{N}=$ nannofossil; $\mathrm{F}=$ foraminifer.

${ }^{c}$ Direct numerical age calibrations (via previously determined magnetostratigraphic data) are not available.
These include the officers, crew, and drilling engineers of JOIDES Resolution, the ODP shipboard technical support team (particularly Skip Hutton and Kevin Rogers for help with the shipboard paleomagnetic measurements), and our colleagues in the Leg 114 shipboard scientific party. We are grateful to Kevin Padley for considerably help with the post-cruise paleomagnetic measurements and to Kate Saull and Christine Tresise, respectively, for their care and patience in drafting the figures and typing the manuscript.

\section{REFERENCES}

Berggren, W. A., Kent, D. V., and Flynn, J. J., 1985. Jurassic to Paleogene: part 2. Paleogene geochronology and chronostratigraphy. In Snelling, N. J. (Ed.), The Chronology of the Geological Record: Geol. Soc. London Mem., 10:141-195.

Butler, R. F., and Lindsay, E. H., 1985. Mineralogy of magnetic minerals and revised magnetic polarity stratigraphy of continental sediments, San Juan Basin, New Mexico. J. Geol., 93:535-554.

Fenner, J. M., 1984. Eocene-Oligocene planktic diatom stratigraphy in the low latitudes and the high southern latitudes. Micropaleontology, 30:319-342.

Gombos, A. M., Jr., and Ciesielski, P. F., 1983. Late Eocene to early Miocene diatoms from the southwest Atlantic. In Ludwig, W. J., Krasheninnikov, V. A., et al., Init. Repts. DSDP, 71 (Pt. 2): Washington (U.S. Govt. Printing Office), 583-684.

LaBrecque, J. L., and Hayes, D. E., 1979. Seafloor spreading history of the Agulhas Basin. Earth Planet. Sci. Lett., 45:411-428.

Lowrie, W., and Alvarez, W., 1981. One hundred million years of geomagnetic polarity history. Geology, 9:392-397.

Martini, E., and Müller, C., 1986. Current Tertiary and Quaternary calcareous nannoplankton stratigraphy and correlations. Newsl. Stratigr., 16:99-112.

Shipboard Scientific Party, 1988. Site 699. In Ciesielski, P. F., Kristoffersen, Y., et al., Proc. ODP, Init. Repts., 114: College Station, TX (Ocean Drilling Program), 151-254.

Wise, S. W., 1983. Mesozoic and Cenozoic calcareous nannofossils recovered by Deep Sea Drilling Project Leg 71 in the Falkland Plateau region, southwest Atlantic Ocean. In Ludwig, W. J., Krasheninnikov, V. A., et al., Init. Repts. DSDP, 71: Washington (U.S. Govt. Printing Office), 481-550.

Zijderveld, J.D.A., 1967. AC demagnetization of rocks: analysis of results. In Collinson, D. W., Creer, K. M., and Runcorn, S. K. (Eds.), Methods in Palaeomagnetism: New York (Elsevier), 254286.

Date of initial receipt: 18 May 1989

Date of acceptance: 30 March 1990 Ms 114B-155 
Table 6. Paleomagnetic datums, Hole 700B.

\begin{tabular}{|c|c|c|c|c|}
\hline $\begin{array}{l}\text { Paleomagnetic } \\
\text { datum }\end{array}$ & $\begin{array}{l}\text { Age } \\
\text { (Ma) }\end{array}$ & $\begin{array}{l}\text { Bracketing samples (core, } \\
\text { section, interval in cm) }\end{array}$ & Depth range (mbsf) & $\begin{array}{l}\text { Mean depth } \\
\text { (mbsf) }\end{array}$ \\
\hline C19N/C19R (?) & 44.06 & $5 \mathrm{R}-2,126$, to $5 \mathrm{R}-3,41$ & $48.10-48.80$ & $48.45 \pm 0.35$ \\
\hline $\mathrm{C} 19 \mathrm{R} / \mathrm{C} 20 \mathrm{~N}(?)$ & 44.66 & $6 \mathrm{R}-1,47$, to $6 \mathrm{R}-1,126$ & $55.36-56.15$ & $55.76 \pm 0.39$ \\
\hline $\mathrm{C} 20 \mathrm{~N} / \mathrm{C} 20 \mathrm{R}$ & 46.17 & $7 \mathrm{R}-2,121$, to $7 \mathrm{R}-4,121$ & $67.10-70.10$ & $68.60 \pm 1.50$ \\
\hline $\mathrm{C} 21 \mathrm{R} / \mathrm{C} 22 \mathrm{~N}(?)$ & 51.95 & $16 \mathrm{R}-2,15$, to $16 \mathrm{R}-2,109$ & $151.54-152.48$ & $152.01 \pm 0.47$ \\
\hline $\mathrm{C} 22 \mathrm{~N} / \mathrm{C} 22 \mathrm{R}(?)$ & 52.62 & $16 \mathrm{R}-6,127$, to $18 \mathrm{R}-1,78$ & $158.66-169.67$ & $164.16 \pm 5.51$ \\
\hline C23N/C23R (?) & 54.70 & $20 \mathrm{R}-2,96$, to $20 \mathrm{R}-3,49$ & $190.35-191.38$ & $190.86 \pm 0.52$ \\
\hline $\mathrm{C} 25 \mathrm{R} / \mathrm{C} 26 \mathrm{~N}(? ?)$ & 60.21 & $29 \mathrm{R}-1,25$, to $29 \mathrm{R}-1,115$ & $266.74-267.64$ & $267.19 \pm 0.45$ \\
\hline $\mathrm{C} 26 \mathrm{R} / \mathrm{C} 27 \mathrm{~N}$ & 63.03 & $32 \mathrm{R}-3,101$, to $32 \mathrm{R}-3,125$ & $299.00-299.26$ & $299.13 \pm 0.13$ \\
\hline $\mathrm{C} 28 \mathrm{R} / \mathrm{C} 29 \mathrm{~N}$ & 65.50 & $36 \mathrm{R}-1,115$, to $36 \mathrm{R}-1,147$ & $327.16-327.47$ & $327.31 \pm 0.16$ \\
\hline $\mathrm{C} 29 \mathrm{~N} / \mathrm{C} 29 \mathrm{R}$ & 66.17 & $37 \mathrm{R}-2,106$, to $37 \mathrm{R}-2,113$ & $333.26-333.33$ & $333.29 \pm 0.04$ \\
\hline C31N/C31R & 69.40 & $38 \mathrm{R}-5,81$, to $39 \mathrm{R}-1,115$ & $342.30-346.14$ & $344.22 \pm 1.92$ \\
\hline C31R/C32N & 71.37 & $40 \mathrm{R}-3,15$, to $40 \mathrm{R}-3,35$ & $357.65-357.85$ & $357.75 \pm 0.10$ \\
\hline $\mathrm{C} 32 \mathrm{R} / \mathrm{C} 33 \mathrm{~N}$ & 74.30 & $43 R-2,15$, to $43 R-2,45$ & $384.66-384.96$ & $384.82 \pm 0.14$ \\
\hline C33N/C33R & 80.17 & $46 \mathrm{R}-3,85$, to $46 \mathrm{R}-3,104$ & $407.35-407.55$ & $407.45 \pm 0.10$ \\
\hline C33R/C34N & 84.00 & $48 \mathrm{R}-6,85$, to $48 \mathrm{R}-6,104$ & $430.85-431.05$ & $430.95 \pm 0.10$ \\
\hline
\end{tabular}




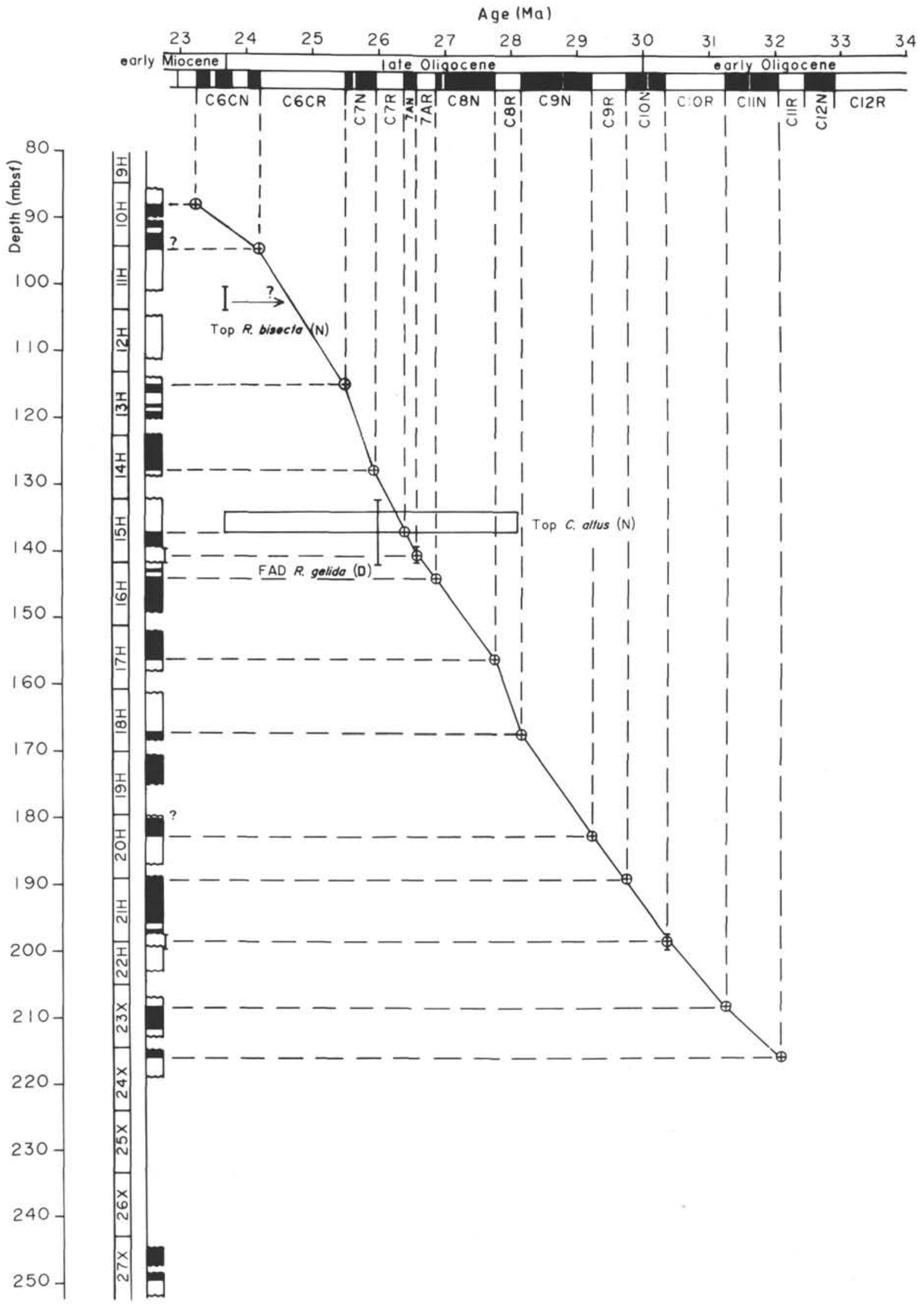

Figure 12. Correlation of the magnetic polarity reversal record in the Oligocene sequence of Hole 699A to the GPTS of Berggren et al. (1985). The biostratigraphic datums are discussed in the text $(\mathrm{N}=$ calcareous nannofossil, $\mathrm{D}=\mathrm{diatom} ; \mathrm{FAD}$ $=$ first-appearance datum). 


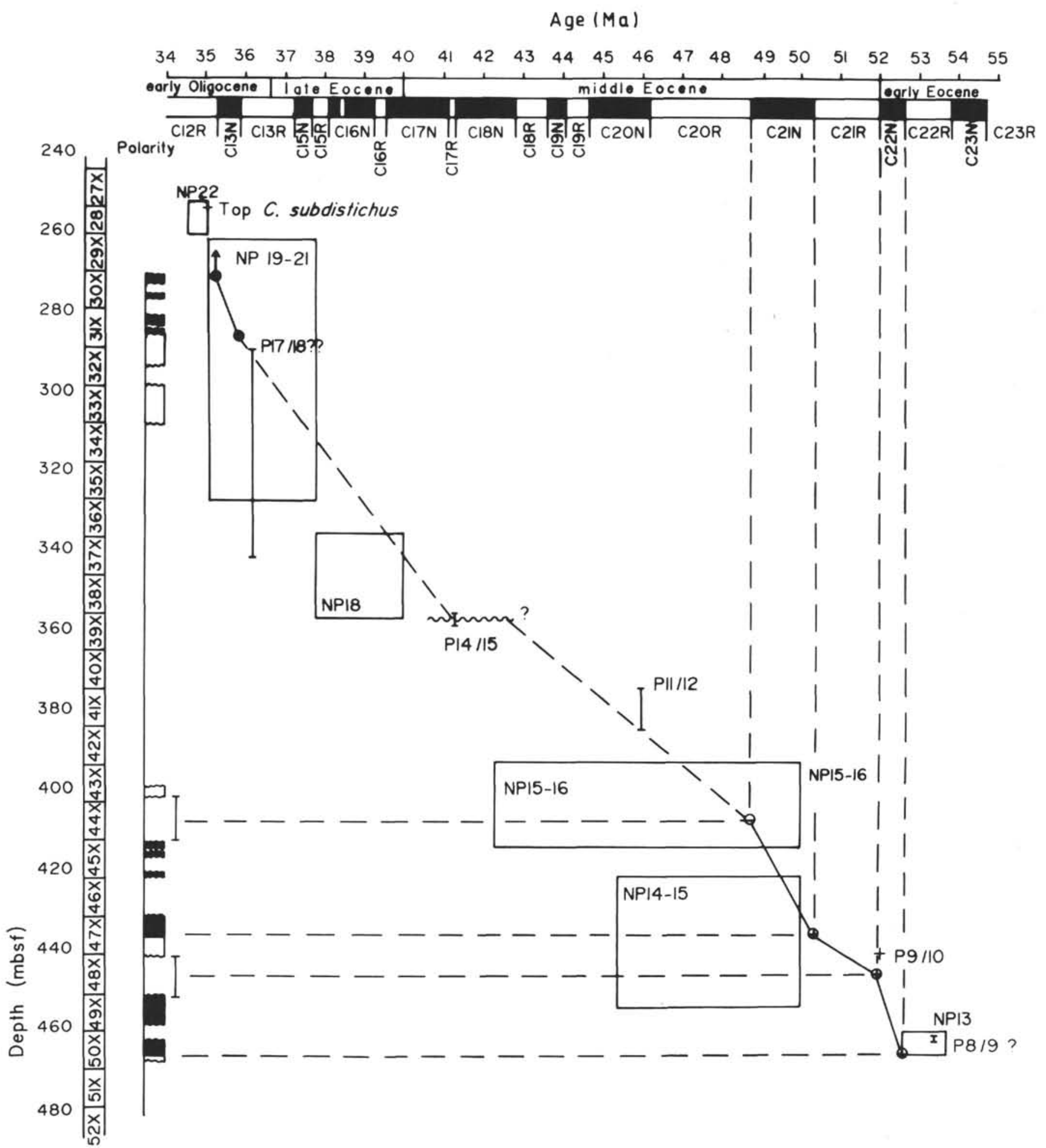

Figure 13. Correlation of the magnetic polarity reversal record in the Eocene sediments of Hole 699A to the GPTS of Berggren et al. (1985). The available biostratigraphic datums for calcareous nannofossil (NP) and foraminifer (P) zones constrain the correlation. 


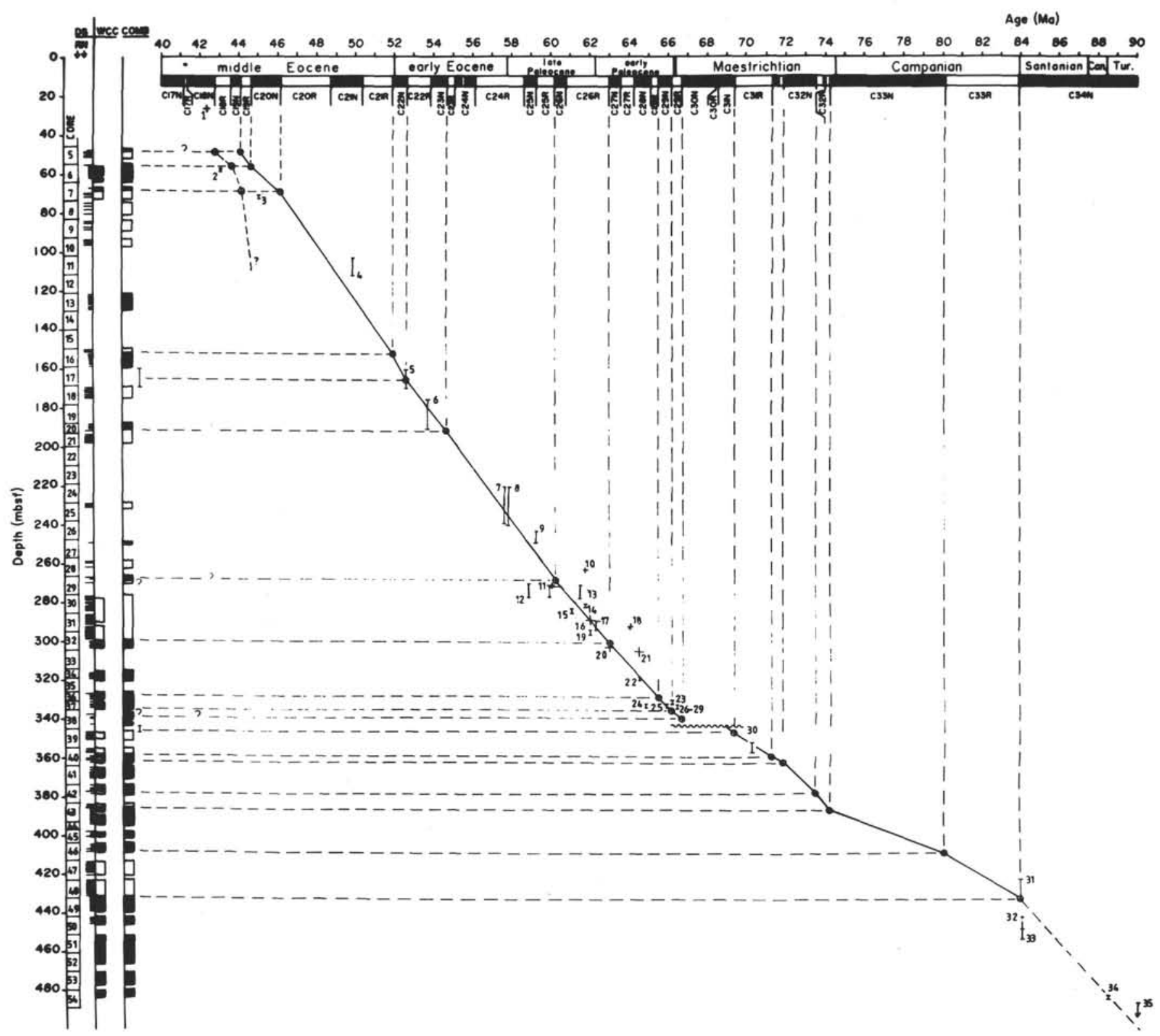

Figure 14. Correlation of the magnetic polarity reversal record in the middle Eocene to Turonian sediments of Hole 700B to the GPTS of Berggren et al. (1985). The numbered biostratigraphic datums (Table 5) constrain this correlation. The WCC and DS columns summarize the raw data from whole-core cryogenic and discrete sample measurements, respectively; COMB represents the combined WCC and DS data. For the discrete sample determinations, short lines represent normal polarity and longer lines reverse polarity. 